San Jose State University

SJSU ScholarWorks

Master's Theses

Master's Theses and Graduate Research

1990

\title{
The effects of zinc on the growth and development of five day old lettuce seedlings (Lactuca sativa) as shown by light and electron microscopy
}

Mikael Niehoff

San Jose State University

Follow this and additional works at: https://scholarworks.sjsu.edu/etd_theses

\section{Recommended Citation}

Niehoff, Mikael, "The effects of zinc on the growth and development of five day old lettuce seedlings (Lactuca sativa) as shown by light and electron microscopy" (1990). Master's Theses. 3282.

DOI: https://doi.org/10.31979/etd.3yve-b2qq

https://scholarworks.sjsu.edu/etd_theses/3282

This Thesis is brought to you for free and open access by the Master's Theses and Graduate Research at SJSU ScholarWorks. It has been accepted for inclusion in Master's Theses by an authorized administrator of SJSU ScholarWorks. For more information, please contact scholarworks@sjsu.edu. 


\section{INFORMATION TO USERS}

The most advanced technology has been used to photograph and reproduce this manuscript from the microfilm master. UMI films the text directly from the original or copy submitted. Thus, some thesis and dissertation copies are in typewriter face, while others may be from any type of computer printer.

The quality of this reproduction is dependent upon the quality of the copy submisted. Broken or indistinct print, colored or poor quality illustrations and photographs, print bleedthrough, substandard margins, and improper alignment can adversely affect reproduction.

In the unlikely event that the author did not send UMI a complete manuscript and there are missing pages, these will be noted. Also, if unauthorized copyright material had to be removed, a note will indicate the deletion.

Oversize materials (e.g., maps, drawings, charts) are reproduced by sectioning the original, beginning at the upper left-hand corner and continuing from left to right in equal sections with small overlaps. Each original is also photographed in one exposure and is included in reduced form at the back of the book.

Photographs included in the original manuscript have been reproduced xerographically in this copy. Higher quality $6 "$ " $\times 9$ " black and white photographic prints are available for any photographs or illustrations appearing in this copy for an additional charge. Contact UMI directly to order.

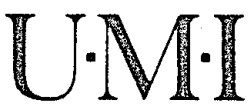

University Microlims Internatıonal

A Bell \& Howel: Intormation Company

300 North ZEeb Road. Ann Arbor. MI 48106-1346 USA

$313761.4700 \quad 800521.0600$ 
The effects of zinc on the growth and development of five day old lettuce seedlings (Lactuca sativa) as shown by light and electron microscopy

Niehoff, Mikael, M.A.

San Jose State University, 1990

Copyright C 1990 by Niehoff, Mikael. All rights reserved.

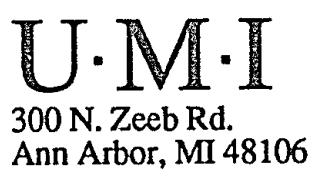





\author{
A THESIS \\ Presented to \\ The Faculty of the department of Biological Sciences \\ San Jose State University
}

In Partial Fulfillment of

The Requirements for the Degree of

Master of Arts

By

Mikael Niehoff

May 1990 


\section{APPROVED FOR THE DEPARTMENT OF BIOLOGICAL SCIENCES:}
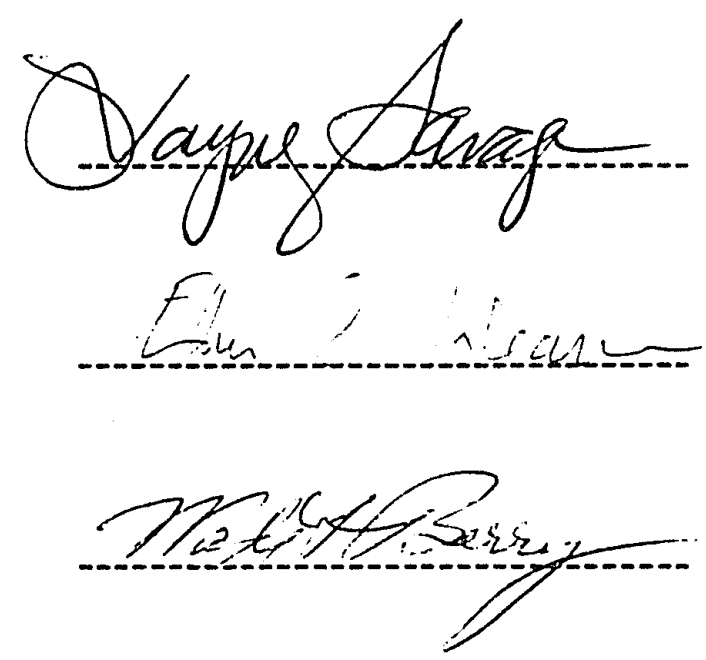

\section{APPROVED FOR THE UNIVERSITY}

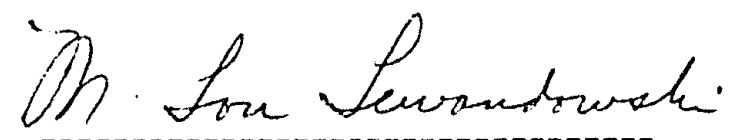




\section{ACKNOWLEDGEMENTS}

I am very grateful for the help and guidance of my committee. Each has contributed significantly to the success of this study. I wish to especially thank Dr. Wayne Savage who gave me the opportunity to pursue this project and who waited patiently while I completed this work.

Many thanks to Dr. Ellen Weaver and Dr. Wade Berry for their suggestions and thorough review of this tert.

Finally, I wish to thank Sharon who encouraged me to complete this work despite the multitude of obligations that I had assumed in the intervening years. 


\begin{abstract}
THE EPFECTS OP ZINC ON THE GROWTH AND DEVELOPMENT OF FIVE DAY OLD LETTUCE SEEDLINGS (Lactuca sativa) AS SHOWN BY LIGHT AND ELECTRON MICROSCOPY

by Mikael Niehoff
\end{abstract}

Lettuce seeds (Lactuca sativa c.v. Grand Rapids) were imbibed and grown for five days in culture solution containing various concentrations of $\mathrm{ZnSO}_{4}$. The seedlings were then examined by light and electron microscopy (SEM and TEM). It was found that lettuce seedlings have an acute toxic threshold near $10 \mathrm{ppm} \mathrm{Zn}$ in solution. The toric effects resulted in a reduction of root length, primordia density and cotyledon growth. SEM examination found that increased zinc levels caused changes in surface structures including changes in capitate trichomes, stomatal arrangement and epidermal integrity. The TEM examination revealed increased deposition of electron dense material in root cells with increased zinc concentrations. 
Table of Contents

page

Abstract

I

Introduction

1

Materials and Methods

Results

table 1

16

table 2

table 3

tahle 4

table 5

19

19

figure 1

20

figure 2

figure 3

20

figure 4

figure 5

21

figure 6

22

22

plates 1-23

$23-45$

Discussion

46

References

53 


\section{INTRODUCTION}

Zinc is a naturally occurring element that tends to be uniformly distributed in various types of soils. In sandstones and carboniferous rocks, zinc concentrations range from $10-30 \mathrm{ppm}$, whereas in argillaceous sediments and shales, it ranges from 80-120 ppm (Pendias, et al. 1984).

Atmospheric contributions of zinc may enhance the concentration of zinc found in surrounding soils. Ernst (1972) studied the extent of airborne zinc pollution of the soils and plants in the vicinity of zinc smelters. He found that the metabolic aclivity of plants and soil micro-organisms was adversely affected by the increased zinc concentrations.

Zinc is an essential nutrient for the normal growth and function of plants. Zinc is involved in the metabolic activity of the plant. It is a component of a variety of enzymes such as dehydrogenases, proteinases, peptidases and phosphohydrolases. Zinc is involved in metabolism of carbohydrates, proteins and phosphates as well as formation of auzins, RNA and ribosomes (Pendias, et al. 1984). Vallee (1976) reported that zinc is essential to multiple processes and. in particular, to the development, division and differentiation of cells. However, when zinc levels exceed the basic requirements for function and growth, adverse reactions begin to occur. Dilling (1926) found that zinc had a deleterious effect on the germination and growth of cress (Lepidium sativum) and mustard (Sinapis alba).

Frow these early beginnings, other researchers have explored the effects of zinc and oiner metals on the growth and development of plants. As the 
environmental implications of metals become more important, the need for applicable research increases.

The effect of zinc has been examined in many plant species. Wu, et al. (1975) measured root lengths in Agrostis stolnifera and found that there was a significant decrease in length with an increase in treatment levels. They also found that the roots complex zinc metals and limit its entry into the shoot. This suggests that roots provide a significant binding site for zinc. Rauser (1973) studied the effects of zinc on bean (Phaseolus vulgaris), soybeans (Glycine max) and corn (Zea mays). The beans and soybeans were planted in vermiculite and the corn sown on moist filter paper. Seven days later, the plants were transplanted to hydroponic cultures and after five days of growth the plants were transferred to treatment solutions for nine days. It was found that 5-10 ppm zinc retarded bean and soybean seedling growth by reducing internode elongation and trifoliate leaflet expansion. Zinc toxicity also manifested itself by leaf discoloration. In corn, zinc content reduced plant height and caused young expanding leaves to become yellowish to white. Rauser also found that zinc toxicity caused changes in cortical parenchyma and zylem vessels in beans and soybeans.

Brown and Wilkins (1985) examined the effects of zinc on the growth of Betula spp. The authors grew seedlings on nutrient agar to which $\mathrm{ZnSO}_{4}$ had been added. After eight weeks of growth, the seedlings were harvested and the stems, roots and leaves were weighed and measured seperately. In all experiments growth was reduced by zinc. It was also discovered that the zinc metal was distributed throughout the plant, but that higher levels occurred in 
the root than in the shoot. In this study, the authors used stem elongation as an index for toxicity.

Wallace and Romney (1977) treated Phaseolus vulgaris with zinc in culture solution. After 26 days of growth they examined the distribution (dry weight basis) of zinc among the roots, stems and leaves. Although the controls tended to accumulate more zinc in the roots than stems or leaves, at elevated levels the distribution tended to be more uniform. The authors also examined cadmium, tin, titanium, chromium and other trace metals. They concluded that the mechanism for binding in or on roots may decrease tozicity of such metals to plants and that retention of such metals could decrease their entry into the food chain. Wallace and Romney believed that root analysis would be necessary to identify the toxicity of trace metals.

Turner et al. (1971) examined the accumulation of $65 \mathrm{Zn}$ in the roots of Agrostis tenius. They found that the cell wall fractions of root homogenates in zinc treated plants was the major site for zinc accumulation. The accumulation was rapid and independent of temperature and $\mathrm{pH}$ which the authors suggest is an exchange adsorption process.

Rauser and Dumbroff (1981) investigated the effects of zinc on Phaseolus yulgaris. Ten day oid seedlings were exposed for 1 or 2 days to $200 \mathrm{um}$ zinc. It was found that abscisic acid levels increased five-fold in the leaves and that zinc also induced stematal closure resulting in a decrease in transpiration.

Robb, et al (1980) found that white beans (Phaseolus vulgaris) grown in hydroponic cultures exhibited rylem vessel wall alterations and gelation of the pit membranes when exposed to ezcess zinc. The transmission electron 
microscopic examination revealed the deposition of electron dense material in the secondary vessel walls.

Berry (1977) determined dose response curves for lettuce (Lactuca sativa) seedlings subjected to acute levels of zinc. Lettuce seeds were imbibed, germinated and grown in culture solution and subjected to a series of increasing concentrations of zinc. Berry measured root length and determined a dose response curve. He found that increasing concentrations resulted in a reduction of root growth.

In a study by Savage et al. (1981), lettuce (Lactuca sativa) seeds were imbibed, germinated and grown in culture solution but subjected to a series of increasing concentrations of copper. The seedlings were examined by scanning electron microscopy after five days of growth. The seedlings were examined for changes in morphology as related to the copper concentration in the culture solution. The authors found that there was a change in root, cotyledon and epicotyl morphology with increased concentrations of copper. As the concentration increased, there was a decrease in primary root length, decrease in number and length of secondary roots, reduction in number and distribution of root hairs and a reduction in the size of cotyledons.

The purpose of this study was to examine changes in morphology and cell ultrastructure with increasing levels of zinc. Light, as well as electron microscopy was utilized to record these observed changes. Lettuce (Lactuca sativa) seedlings were grown in solution at various concentrations of zinc. Zinc sulfate $\left(\mathrm{ZnSO}_{4}\right)$ was added to the Hoagland's nutrient solution to provide the necessary concentrations. Seedlings were grown in solution to eliminate the effects of soil relationships on zinc uptake dynamics. These effects 
include competition from other ions, combination of other metals, nutrient availability and the effects of soil pH on uptake. In addition, this study examined other anatomical structures and utilized a large sample size and multiple repetitions to increase the statistical value of the data. This study did not examine the relationship of other metals on zinc uptake or toricity since this has been covered by other researchers ( $\mathrm{W} u$, et al. 1975; Patel, et al. 1976; Wallace, et al. 1980; Wallace, 1982; and Pendias, et al. 1984).

It is hoped that this study has provided additional evidence relating to zinc toxicity, as well as the application of electron microscopy as a valuable tool in this search. 


\section{MATERIALS AND METHODS}

Seeds of Sativa lactuca L. c.v. Grand Rapids were grown in 2L Erlenmeyer flasks containing $1 / 10$ strength Hoaglands solution for a period of 5 days $(120 \mathrm{hrs})$. Each flask contained $1 \mathrm{~L}$ of solution and 50 seeds. The $1 / 10$ Hoagland's nutrient solution consisted of: $0.5 \mathrm{mM} \mathrm{Ca}\left(\mathrm{NO}_{3}\right)_{2}, 0.5 \mathrm{mM} \mathrm{KNO}_{3}$, $0.2 \mathrm{mM} \mathrm{MgSO}_{4}, 0.1 \mathrm{mM} \mathrm{KH}_{2} \mathrm{PO}_{4}$, FeEDTA equivalent to $0.5 \mathrm{mg}$ of Fe, $4.86 \mu \mathrm{m}$ $\mathrm{H}_{3} \mathrm{BO}_{3}, 0.92 \mu \mathrm{m} \mathrm{MnCl} \cdot 4 \mathrm{H}_{2} \mathrm{O}, 0.08 \mu \mathrm{m} \mathrm{ZnCl}, 0.03 \mu \mathrm{m} \mathrm{CuCl} 2 \cdot \mathrm{H}_{2} \mathrm{O}, 0.01 \mu \mathrm{m}$ $\mathrm{Na}_{2} \mathrm{MOO}_{4} \cdot 2 \mathrm{H}_{2} \mathrm{O}$ (Hoagland and Arnon, 1950). Zinc sulfate was added to each flask, except the control, to give solute concentrations of $1.0,5.0,10.0,20.0$, 30.0, 60.0, and $100.0 \mathrm{ppm}$ zinc. Each treatment had 3 replications.

Each flask was gently aerated in a growth chamber with the following environmental conditions: Light $2000 \mathrm{ft} / \mathrm{c}$, day length $16 \mathrm{hrs}$, day temp $20^{\circ} \mathrm{C}$ and night temp $15^{\circ} \mathrm{C}$. A small pump provided the air source for aeration. The air was passed through activated charcoal and then through a sealed erlenmeyer flask containing $3 \mathrm{X}$ distilled $\mathrm{H}_{2} \mathrm{O}$ before entering the flasks containing the seeds. This created a gentle bubbling action that not only orygenated the Hoaglands solution, but prevented developing seedlings from attaching to one another. Only one treatment level was performed at a time.

Twelve hundred seedlings were cultured for the study. However, only 25 randomly selected seedlings from each treatment replication were examined by light microscopy. 
Light Microscopy

At the end of 120 hours the seedlings were harvested. The seedlings were washed 3 times with $0.1 \mathrm{M}$ cacodylate buffer (pH:6.9) and then fized for 3 hours in ice-cold $2.5 \%$ glutaraldehyde in $0.1 \mathrm{M}$ cacoldylate buffer (pH:6.9). The seedlings were then washed three times in $0.1 \mathrm{M}$ cacodylate buffer and dehydrated through a graded aqueous ethanol series to $100 \%$ ethanol.

Twenty-five fixed seedlings from each treatment replication (75/treatment) were examined with a Nikon dissection scope. The microscope was fitted with a calibrated ocular micrometer. Each seedling was examined and measurements obtained for root and root cap length, cotyledon surface area, eophyll length and number of root primordia. A total of 600 seedlings were examined and the results tabulated. Statistical analysis of the data was performed to determine significant changes in seedling morphology related to zinc concentration.

\section{Scanning Electron Microscopy}

Several seedlings from each treatment were removed after fixation/dehydration and prepared for critical point drying. The seedlings were placed in a fine wire mesh basket and placed in the Denton DCP-1 critical point drying apparatus. The seedlings were critical point dried with liquid $\mathrm{CO}_{2}$. Upon removal from the critical point dryer, the seedlings were carefully affired to SEM stubs with double-stick tape. The stubs were then placed in a Technics HummerII sputter coater. A 100 angstrom layer of gold palladium was applied. 
The treated stubs were then viewed in an International Scientific Instrument ISI-III scanning eiectron microscope (SEM).

Three main areas were examined: the root-hypocotyl internode, cotyledons and root surface. Photographs of these areas were obtained using the Polaroid 545 camera attachment and Polaroid type 55 positive/negative film. The negatives were fired in $18 \%$ sodium sulfate.

\section{Iransmission Electron Microscopy}

Fixed root tissue from $0,5.0$ and $20.0 \mathrm{ppm} \mathrm{Zn}$ treatments was prepared for transmission electron microscope (TEM) examination. Seedlings from the glutaraldehyde fixation process were removed and treated with the secondary fixative osmium tetroxide. The seedlings were treated with $2.0 \%$ osmium tetroxide in $0.1 \mathrm{M}$ cocadylate buffer ( $\mathrm{pH}: 6.9$ ) for 2 hours, then washed three times with $0.1 \mathrm{M}$ cacodylate buffer (pH:6.9) and then dehydrated through a graded aqueous ethanol series to $100 \%$ ethanol. The seedlings were then placed in propylene oxide to insure complete dehydration. The root tissue was excised from the seedling and cut into sections less than $2.0 \mathrm{~mm}$ in length. These sections were then processed through a graded series of propylene oxide and Spurr's resin until 100\% spurr's resin was achieved. The root sections were then placed in resin molds and placed in a vacuum oven for $16 \mathrm{hrs}$ at $35^{\circ} \mathrm{C}$.

Sections for TEM examination were made using a Sorvall Porter-Blum microtome. The sections were placed on Pelco 1 GCS00 grids which had been previously coated with Formvar and carbon coated in a Jeol JEE $4 \mathrm{C}$ vacuum 
evaporator. The sections were examined in a Zeiss EM 109 transmission electron microscope.

\section{Atomic Absorotion}

An atomic absorption spectrophotometric analysis was performed on the $1 / 10$ Hoaglands solution to determine background levels of zinc in the nutrient solution. Since zinc is a required nutrient for normal growth and development, it could not be eliminated from the solution. Therefore the background level needed to be determined. A $1000 \mathrm{ug} / \mathrm{ml}$ solution of zinc was created by dissolving $1.0 \mathrm{~g}$ of zinc in $40 \mathrm{ml} 1: 1 \mathrm{HCl}$ and then diluted to 1 liter. Additional dilutions were made from this stock solution.

A Varian Techtron atomic absorption spectrophotometer model 1200 was utilized for analysis. At a wavelength of $213.9 \mathrm{~nm}$, the detection limit for zinc was $0.002 \mathrm{ug} / \mathrm{ml}$. Using a standard solution of $1 \mathrm{ug} / \mathrm{ml}$ and a control, the zinc level was determined for the $1 / 10$ Hoaglands nutrient solution. Three replications of the $1 / 10$ Hoaglands solution were analyzed. 


\section{RESULTS}

\section{Morphology of control}

The five-day old seedlings had an average root length of $36.59 \mathrm{~mm}$. Only $10 \%$ of the seedlings had a lateral root which averaged less than $1 \mathrm{~mm}$ in length. The root caps averaged $0.99 \mathrm{~mm}$ in length and was rounded at its apex. The root hairs were well developed and occurred at a point beginning $2 \mathrm{~mm}$ proximal to the root cap and extending to the root/hypocotyl internode. The root hairs were uniform in length and distribution.

The cotyledons were spatulate and usually emarginate. The cotyledons averaged $7.14 \mathrm{~mm}$ in length and $2.60 \mathrm{~mm}$ in width and contained numerous multicellular capitate trichomes. The stomata were anomocytic in arrangement and occurred on both surfaces of the cotyledons.

The eophyll has an average length of $0.98 \mathrm{~mm}$. The eophyll exhibited convolute ptyxis and contained numerous multicellular capitate trichomes. The stomata were tine same as found on the cotyledons.

\section{Light Microscopy}

A total of 75 seedlings per treatment was examined by light microscopy. Measurements were obtained of root length, root cap length, number of root primordia, cotyledon length and width and eophyll length.

The root length was measured from the tip of the root cap to the root/hypocotyl internode. The root/hypocotyl internode was clearly demarcated by the cessation of root hairs. Secondary roots were also measured. These were measured from the root cap tip to the primary root 
junction. Since the objective was to measure total root growth, both of these values were combined to derive a single value, (figure 1).

An analysis of variance (anova) was performed for each treatment to determine if there was a significant difference between each replication. Table 1 illustrates that there was no significant difference between replications for each treatment. A between group anova was performed for all treatment levels. Table 2 shows that there is a significant difference between treatment levels. Initially a Newman-Keuls multiple range test was to be utilized. However, because the error mean square (table 2) was so small, this statistical test could not be used. Instead, a log transformation for each replication mean was performed. The transformed data were plotted on a semi-log scale graph (figure 2 ). A regression coefficent analysis was utilized on the transformed data. The first three treatments created a flat line, with a decline following. Therefore, the graph was treated as two lines: the first line being comprised of 0,1 , and $5 \mathrm{ppm}$ zinc and the second line being comprised of $10,20,30$, and $60 \mathrm{ppm}$ zinc. One hundred ppm was removed because of the almost identical results to $60 \mathrm{ppm}$ which had the effect of flattening out the graph and skewing the results. The result of this analysis are shown in Table 3. The regression coefficent analysis shows that there is no significant difference between 0,1 , and $5 \mathrm{ppm}$ zinc and that there is no significant difference between $10,20,30$ and $60 \mathrm{ppm}$ zinc. The regression coefficent analysis shows that there is a significant difference between the two groups of data ( $p<.025)$. Essentially, a tozic threshold occurs at a point between 5 and $10 \mathrm{ppm}$ zinc and is evident as a decline in total root length. 
The root cap length was measured on 600 seedlings(75/treatment). The length was determined by measuring from the root tip to the point where the scleritized cells end. This was clearly defined when using the backfield illumination on the dissection microscope. The data were graphed (figure 3 ). It is evident that there is a reduction in cap length with an increase in zinc concentration.

The root primordia were distinct and easy to count during light microscopy examination. Figure 5 shows the density of primordia per millimeter. It is evident that the density initially decreases and then at 10.0 and $20.0 \mathrm{ppm}$ zinc there is an increase in density followed by a dramatic decrease in density of primordia.

A total of 1200 cotyledons was examined (150/treatment). It was found that the increase in zinc levels resulted in the appaarance of necrosis of the cotyledons. These generally appeared above the $30 \mathrm{ppm}$ treatment level.

The cotyledon length and width were measured. These values were then used to determine the total surface area. Since the cotyledons were shaped like an ellipse, the formula for an ellipse was used to calculate the area. The value was then doubled to give total leaf surface area. Table 4 shows the results for each treatment. An anova was performed on the data and showed a significant difference ( $f<05$ ). A Dunnetts test for comparing a control mean to each other mean was used. The results are tabulated in table 5. At 0.05 , there is a significant difference between all treatments, but at 0.01 there is no significant difference between the control and $1.0 \mathrm{ppm}$ zinc. 
The mean for each treatment was plotted (figure 4). It is obvious from the graph that there is an increase in surface area to $5.0 \mathrm{ppm}$ and is then followed by a marked decline. Again, there is the occurrence of a toxic threshold located between 5.0 and $10.0 \mathrm{ppm}$ zinc.

The eophyll was measured from the tip of the eophyll to its origin at the stem. Six hundred seedlings were measured ( $75 /$ treatment). The data were plotted (figure 6). There is an initial increase in length followed by a decline in length. The greatest length is found at $5 \mathrm{ppm} \mathrm{Zn}$, which corresponds to a similar response found in cotyledon surface area (table 4).

\section{Atomic Absorotion Analysis}

The atomic absorption analysis revealed that the $1 / 10$ strength Hoagland's solution contained 0.08 to $0.1 \mathrm{ppm}$ of zinc.

Scanning Electron Microscopy (SEM)

The SEM was used to examine the external morphology of the treated seedlings. The primary areas examined included: roots, root hairs, and cotyledons.

The control seedlings had an average root length of $36.59 \mathrm{~mm}$ and show abundant root hairs (plate 1). The root hair structures appeared uniform in length and even in distribution. The surface of the root is intact and showed no deformity or disruption. The surface area of each cotyledons averaged $29.00 \mathrm{~mm}^{2}$, and each cotyledon showed evenly distributed normal stomata. 
As the zinc concentration increases, there is an obvious decrease in root hair length and abundance. At 5 ppm zinc (plate 3), it becomes evident that a marked change has occurred. The root hairs are decreasing in length and appear distorted. The usually cylindrical root hairs are twisted and convoluted. As the concentration increases (plates 4-8) the root hairs decrease in length and frequency until at $100 \mathrm{ppm}$ zinc they appear nearly vestigial.

In conjunction with the changes in root hair structures, the surface of the primary root undergoes corresponding changes. An examination of plates 1-8 show that the root surface itself becomes irregular in appearance. These changes are probably related to the decrease in overall root length with increasing concentrations (figure 1) of zinc.

The cotyledons at each concentration was examined. The surface area of controls averaged $29.0 \mathrm{~mm}^{2}$ and showed normal and evenly distributed stomata (plate 9), as well as normal multicellular capitate trichomes. At 10 ppm zinc, there were changes in the sotyledon surface (plate 12). The. surface took on a rough texture and the trichomes have become stunted. At $20 \mathrm{ppm}$ zinc (plate 13), the guard cells of the stomata were affected. The guard cells appeared swollen and slightly elevated from the cotyledon surface.

As the concentration increased (plates 14-16), the cotyledon surface becomes increasingly rough in appearance, the capitate trichomes disappear and the stomata occur less frequently. 


\section{Transmission Electron Microscopy (TEM)}

The TEM examination revealed that there was an obvious increase in electron dense material along the cell wall with an increase in treatment concentration. Specimens examined critically were grown in 0,5 , and 20 ppm zinc. These represent the control and a treatment level above and below the acute toric threshold of $10 \mathrm{ppm}$ zinc. The examination was focused on the cells surrounding the vascular tissue. This area was chosen since these will be the first cells to be subjected to deposition and storage of transported materials (i.e. zinc or zinc-complezes).

Examination of plates 17,18 , and 19 illustrates the increase of electron dense material with increasing concentrations. Plates $20(0 \mathrm{ppm} \mathrm{Zn})$ and 21 ( $5 \mathrm{ppm} \mathrm{Zn}$ ) are examples of vascular tissue. Plate 21 shows areas of increased electron density along the cell walls when compared to plate 20 .

Plates $22(5 \mathrm{ppm} \mathrm{Zn})$ and $23\left(20 \mathrm{ppm} \mathrm{In}_{\mathrm{n}}\right.$ ) concentrate along a cell wall. The cell wall at $20 \mathrm{ppm}$ zinc appears irregular and pitted. There is also a wider band of electron dense material compared to $5 \mathrm{ppm}$ zinc. 


\section{Iable 1 Total Boot Length Analysis of Variance (within group)}

$\begin{array}{lrrl}\text { Control } & & & \\ & \text { SS } & \text { DF } & \text { MS } \\ \text { Total } & 2097.79 & 74 & \\ \text { Groups } & 63.44 & 2 & 31.72 \\ \text { Error } & 2034.34 & 72 & 28.25 \\ \text { Fo.05(1)2,72 }=3.13 & F=1.12 & \text { Do not reject } H_{0}\end{array}$

Leopm

$\begin{array}{lccc} & \text { SS } & \text { DF } & \text { MS } \\ \text { Total } & 336.23 & 74 & \\ \text { Groups } & 16.19 & 2 & 8.09 \\ \text { Error } & 320.04 & 72 & 4.45 \\ \text { F0.05(1)2,72=3.13 } & F=3.13 & \text { Do not reject Ho }\end{array}$

$5.0 \mathrm{pom}$

$\begin{array}{lccc} & \text { SS } & \text { DF } & \text { MS } \\ \text { Total } & 608.68 & 74 & \\ \text { Groups } & 8.26 & 2 & 4.13 \\ \text { Error } & 600.42 & 72 & 8.34 \\ \text { F0.05(1)2,72=3.13 } & F=0.495 & \text { Do not reject Ho }\end{array}$

$10.0 \mathrm{pom}$

\begin{tabular}{lccc}
\hline & SS & DF & MS \\
Total & 406.53 & 74 & \\
Groups & 13.19 & 2 & 6.59 \\
Error & 393.34 & 72 & 5.46 \\
F0.05(1)2,72 $=3.13$ & $F=1.20$ & Do not reject $H_{0}$.
\end{tabular}

2Qlepom

$\begin{array}{lccc} & \text { SS } & \text { DF } & \text { MS } \\ \text { Total } & 480.73 & 74 & \\ \text { Groups } & 5.10 & 2 & 2.55 \\ \text { Error } & 475.63 & 72 & 6.60 \\ \text { Fo.05(1)2,72=3.13 } & F=0.38 & \text { Do not re ject } H_{0}\end{array}$


Iable 1 continued

$30.0 \mathrm{ppm}$

$\begin{array}{lccc} & \text { SS } & \text { DF } & \text { MS } \\ \text { Total } & 174.80 & 74 & \\ \text { Groups } & 0.64 & 2 & 0.32 \\ \text { Error } & 174.16 & 72 & 2.42 \\ \text { Fo.05(1)2,72=3.13 } & F=0.13 & \text { Do not reject } H_{0}\end{array}$

$60.0 \mathrm{ppm}$

\begin{tabular}{lccc}
\hline & SS & DF & MS \\
Total & 27.41 & 74 & \\
Groups & 0.70 & 2 & 0.35 \\
Error & 26.71 & 72 & 0.37 \\
Fo.05(1)2,72=3.13 & $F=0.94$ & Do not reject $H_{0}$
\end{tabular}

$1000 \mathrm{ppm}$

$\begin{array}{lccc} & \text { SS } & \text { DF } & \text { MS } \\ \text { Total } & 15.86 & 74 & \\ \text { Groups } & 1.06 & 2 & 0.53 \\ \text { Error } & 14.80 & 72 & 0.20\end{array}$

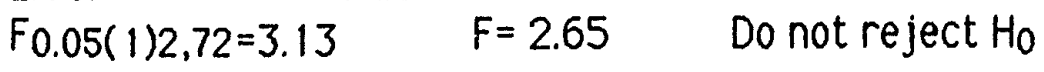

$H_{0}=$ null hypothesis

$F_{0}=F$ distribution nuii nypothesis

$F=$ critical value of the F-Distribution 
Table 2 Total Root Length Analysis of Variance (between groups)

\begin{tabular}{|l|c|c|c|c|c|c|c|r|}
\hline PPM & 0 & 1.0 & 5.0 & 10.0 & 20.0 & 30.0 & 60.0 & 100.0 \\
\hline Mean & 36.59 & 34.65 & 35.16 & 26.29 & 15.50 & 13.40 & 4.72 & 4.34 \\
\hline
\end{tabular}

$N=600$

SS DF MS

Total $\quad 96544.00 \quad 600$

$\begin{array}{llll}\text { Group } & 96591.55 & 7 & 13798.79\end{array}$

$\begin{array}{llll}\text { Error } & 47.55 & 592 & 0.08\end{array}$

$H_{0}: F 0.05(1) 7,592=2.03 \quad H_{A}: F=13798.79 / 0.08=172484.88$

Therefore reject $\mathrm{H}_{0}$ :

Iable 3 Leg Transformation Regression Analysis

\begin{tabular}{|l|c|c|c|c|c|c|c|c|}
\hline PPM & 0 & 1.0 & 5.0 & 10.0 & 20.0 & 30.0 & 60.0 & 100.0 \\
\hline LOgX & 1.55 & 1.54 & 1.55 & 1.41 & 1.19 & 1.12 & 0.67 & 0.63 \\
\hline & 1.58 & 1.55 & 1.54 & 1.43 & 1.18 & 1.13 & 0.67 & 0.65 \\
\hline & 1.57 & 1.54 & 1.54 & 1.42 & 1.20 & 1.13 & 0.69 & 0.63 \\
\hline
\end{tabular}

Regression 1: $0,1.0$ and $5.0 \mathrm{ppm}$

Regression 2: $10.0,20.0,30.0$ and $60.0 \mathrm{ppm}$

$\begin{array}{cccccccc} & x^{2} & x y & y^{2} & n & b & \text { resid } & \text { resid } \\ \text { Regress } 1 & 42 & 0.14 & 0.01 & 9 & .003 & .010 & 7\end{array}$

$\begin{array}{llllllll}\text { Regress } 2 & 4200 & 60 & 0.87 & 12 & .014 & .010 & 10\end{array}$

Pooled reg

Common reg $4242 \quad 60.14 \quad 0.88$

$F=\frac{(0.027-0.02) / 1.0}{0.02 / 17}=\frac{0.07}{.001}=7$

$F_{0.05}(1) 1,17=4.45$

Re ject Ho: $.025>p>01$ 
Iable 4 Leaf Surface Area Analysis of Variance

\begin{tabular}{|c|c|c|c|c|c|c|c|c|c|}
\hline $\mathrm{ppm}$ & 0 & \multicolumn{2}{|c|}{1.0} & 5.0 & 10.0 & 20.0 & 30.0 & 60.0 & 100.0 \\
\hline mean* & 29.0 & \multicolumn{2}{|c|}{29.55} & 33.80 & 28.24 & 26.02 & 26.84 & 22.73 & 20.31 \\
\hline \multicolumn{10}{|c|}{ * values in $\mathrm{mm}^{2}$} \\
\hline \multicolumn{10}{|l|}{$N=1200$} \\
\hline & \multicolumn{4}{|c|}{ SS } & \multicolumn{2}{|l|}{ DF } & \multicolumn{3}{|l|}{ MS } \\
\hline Total & \multicolumn{4}{|c|}{23440.21} & \multicolumn{2}{|l|}{1200} & & & \\
\hline Group & \multicolumn{4}{|c|}{18331.67} & \multicolumn{2}{|l|}{7} & \multicolumn{3}{|l|}{2618.81} \\
\hline Error & \multicolumn{4}{|c|}{5108.54} & \multicolumn{2}{|l|}{1193} & \multicolumn{2}{|c|}{4.28} & \\
\hline \multicolumn{4}{|c|}{$\begin{array}{l}H_{0}: F_{0.05}(1) 7,1193=2.01 \\
\text { Therefore reject } H_{0}\end{array}$} & \multicolumn{4}{|c|}{$F=2618.18 / 4.28=611.87$} & & \\
\hline \multicolumn{10}{|l|}{ Table 5} \\
\hline 1 & 2 & $?$ & 3 & & 4 & 5 & 6 & 7 & 8 \\
\hline 33.80 & 29 & 55 & 29 & & 28.24 & 26.84 & 26.02 & 22.73 & 20.31 \\
\hline
\end{tabular}

* means are ranked from table 4.

\begin{tabular}{|c|c|c|c|c|c|}
\hline & & SE & $\left|q^{\prime}\right|$ & 90.05 & $150 \%$ \\
\hline 3 vs 1 & $|29.00-33.80|=4.80$ & .24 & 20.00 & 1.92 & 2.56 \\
\hline 3 vs 2 & $|29.00-29.55|=0.55$ & & 2.29 & 1.64 & 2.33 \\
\hline vs 4 & $|29.00-28.24|=0.76$ & & 3.17 & 1.64 & 2.53 \\
\hline vs 5 & $|29.00-26.84|=2.16$ & & 9.00 & 1.92 & 2.56 \\
\hline vs 6 & $|29.00-26.02|=2.98$ & & 12.42 & -- & -- \\
\hline vs 7 & $|29.00-22.73|=6.27$ & & 26.13 & -- & -- \\
\hline vs 8 & $|29.00-20.3| \mid=8.69$ & & 36.21 & -- & \\
\hline
\end{tabular}

No significant difference between control and $1.0 \mathrm{ppm}$ at 0.01 level of significance. 
Figure 1 Total meot Leagti

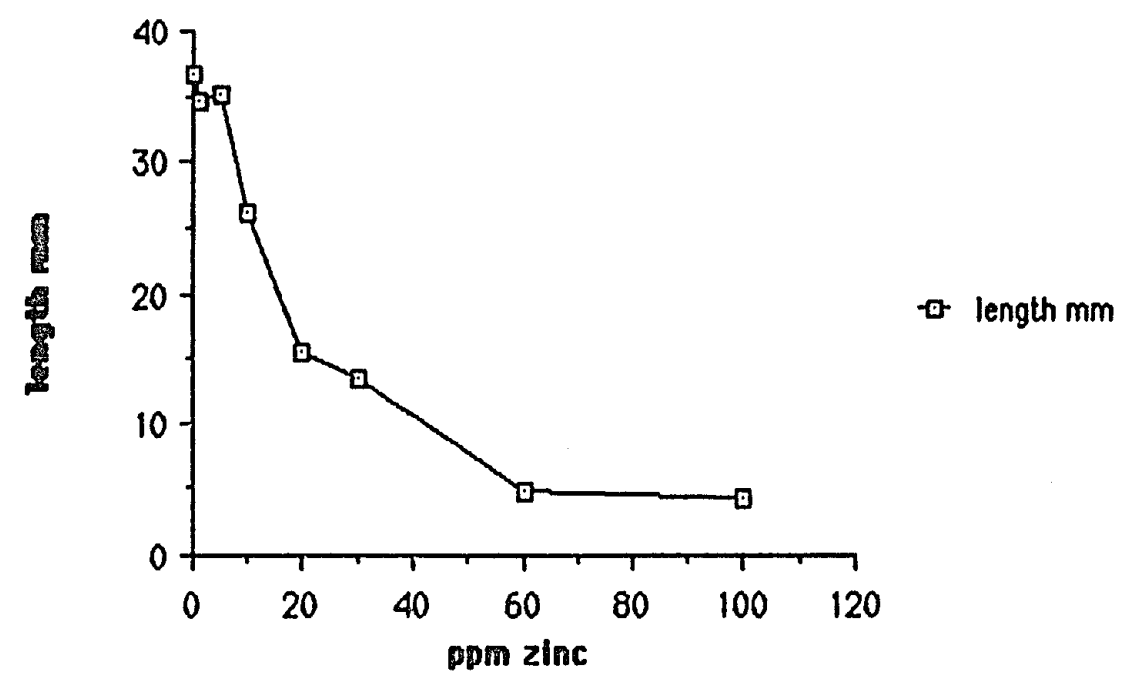

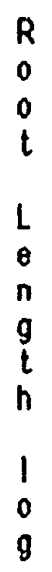

Figare 2 Root Length (log)

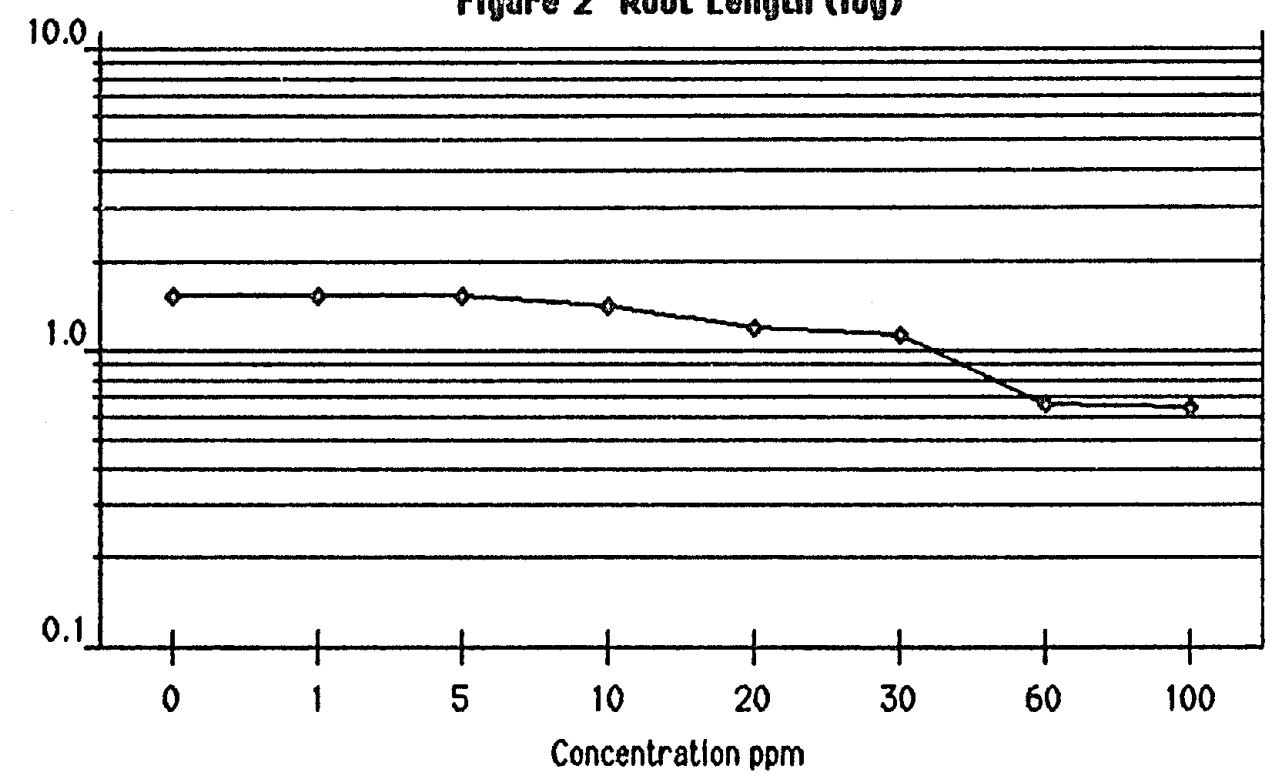

- root length(log) 
Fingro a Root cao Lagen

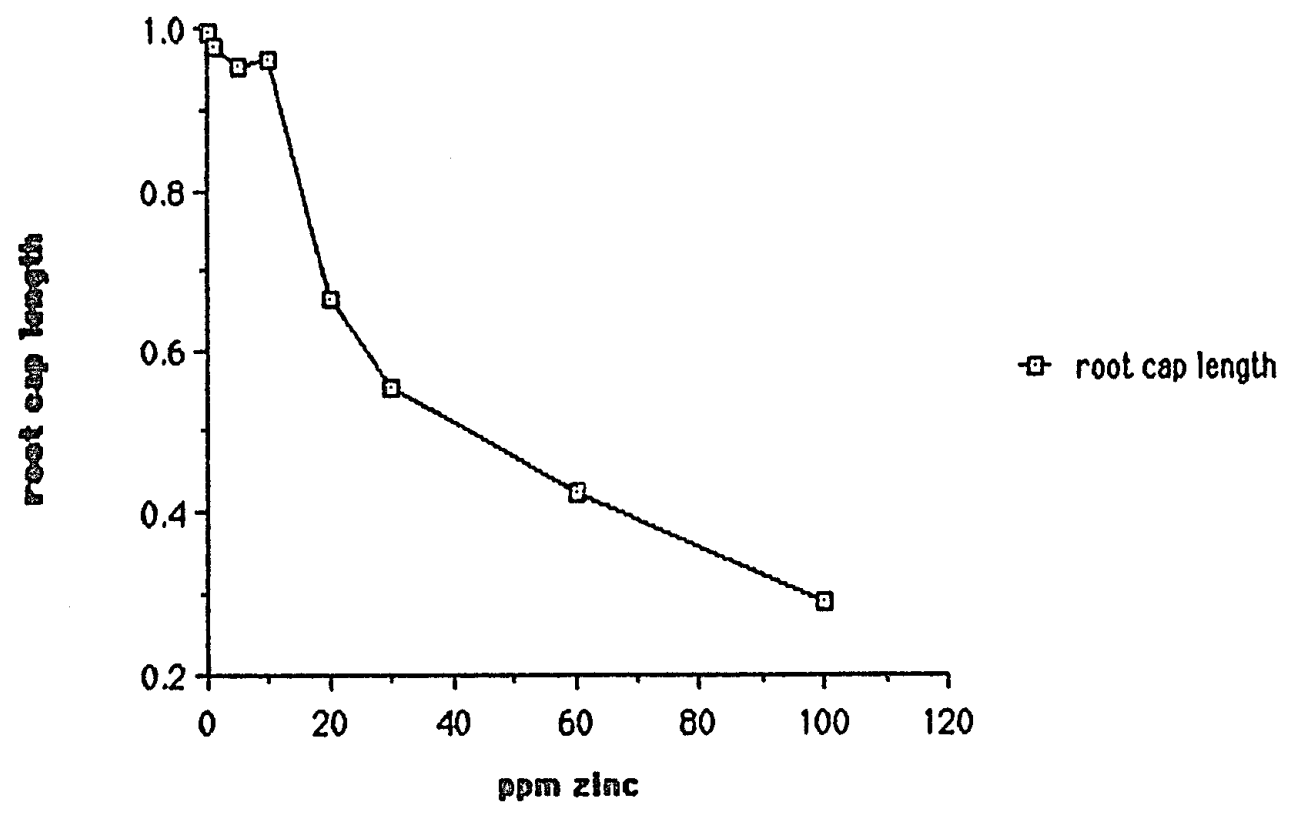

Figere 4 Cosyleson Sorlece Ares

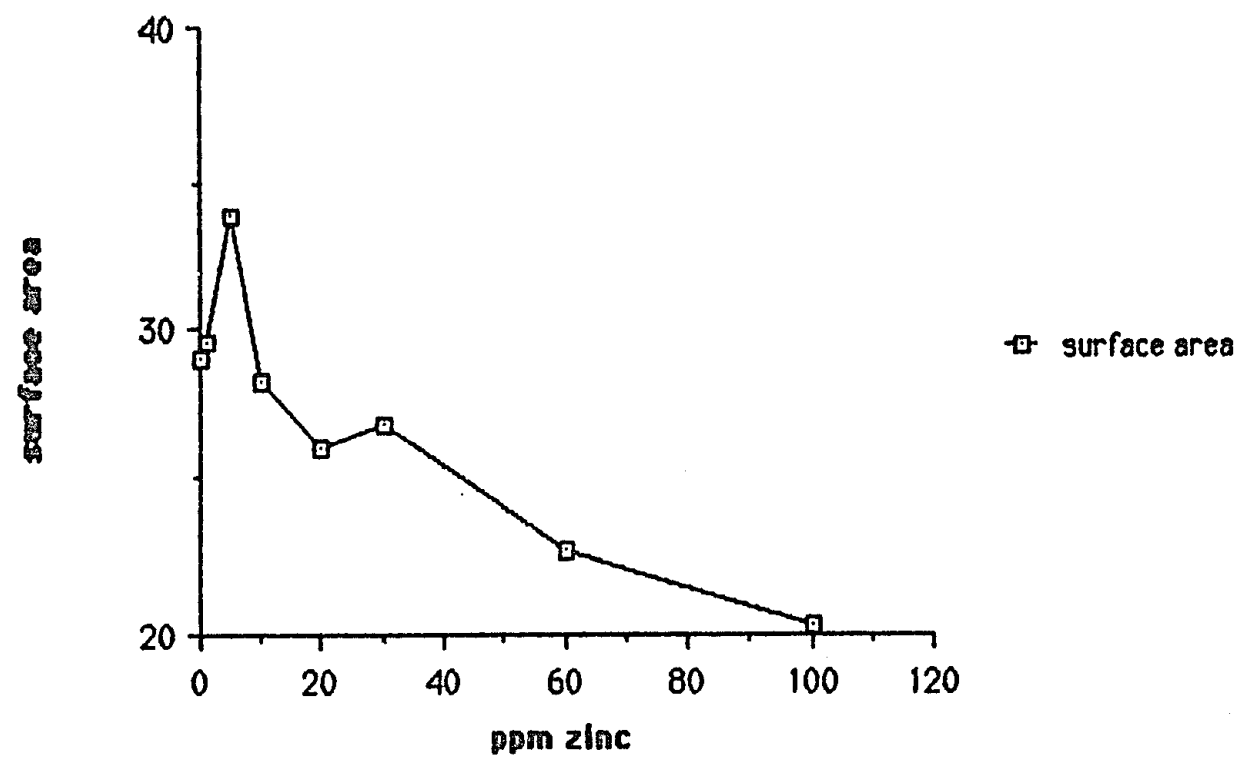


Pigere 5 Primordia Devity

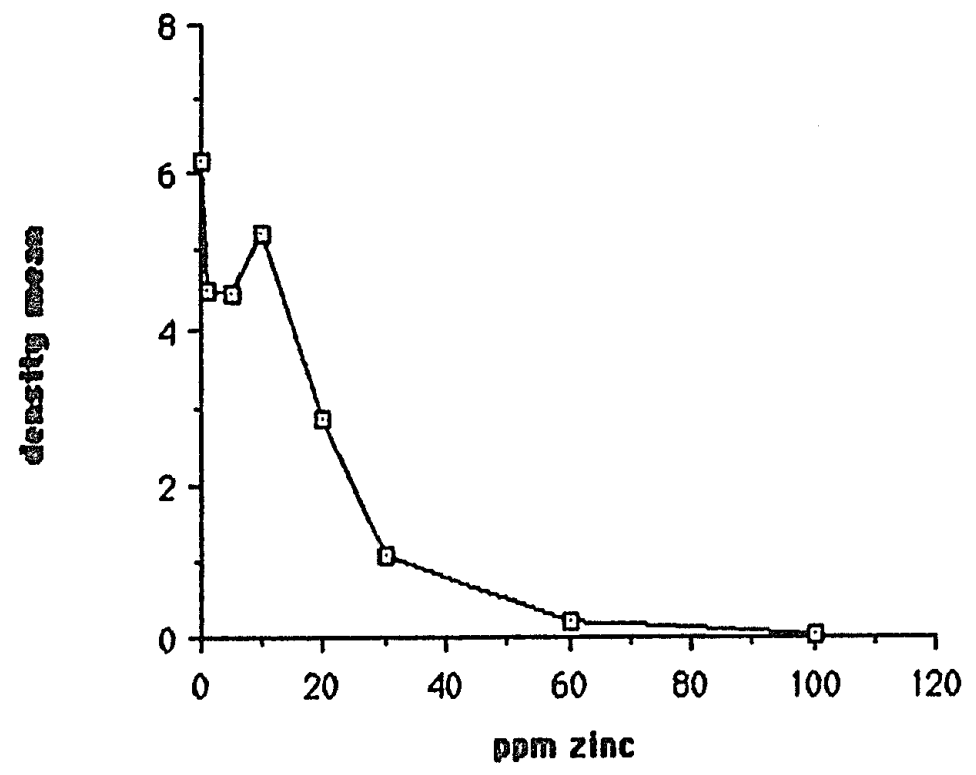

- density mean

Figere 6 Eephyll Leagen

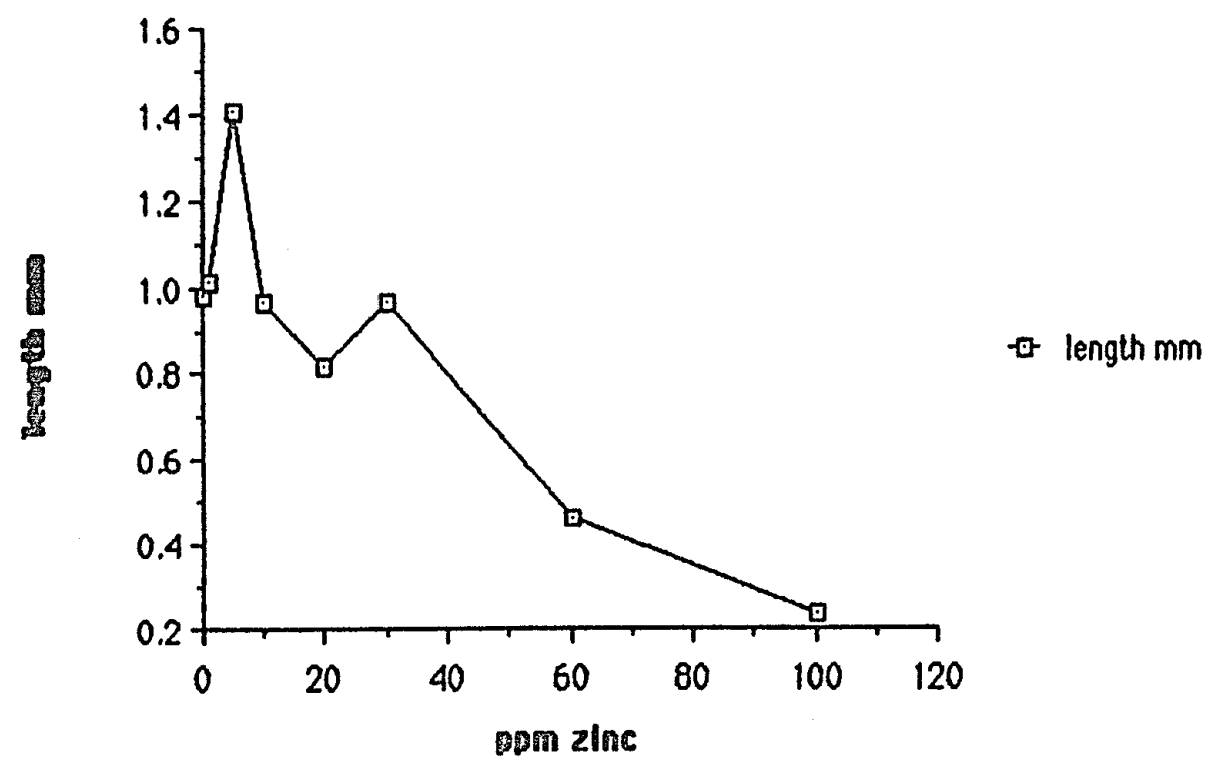




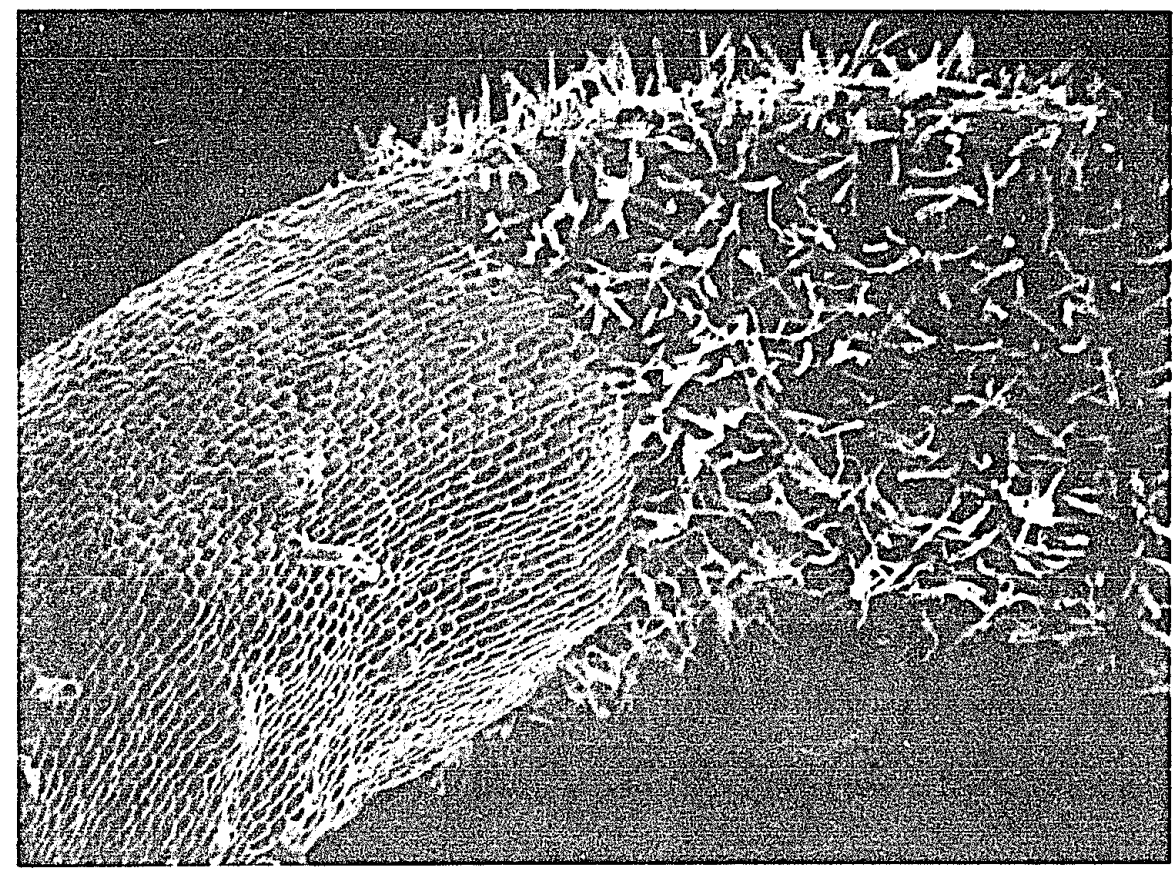

Plate 1. Control $(0 \mathrm{ppm})$ : Lettuce seedling primary root showing abundant root hairs that are uniform in length and distribution. 120X Legend: R-root hairs E-epidermis $\mathrm{H}$-hypocotyl internode 


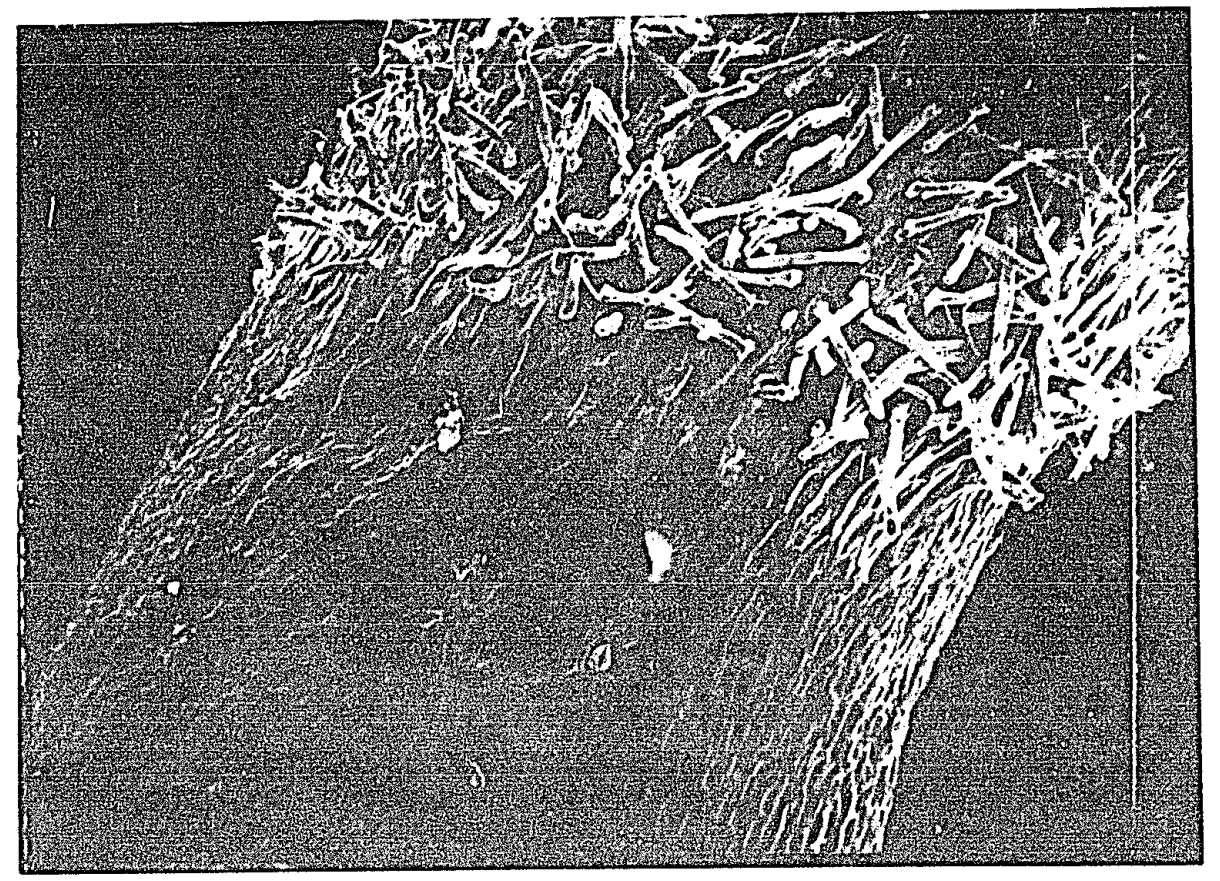

Plate 2. 1 ppm: micrograph shows no difference from the control. Root hairs are abundant and uniform in distribution and appearance. 160X Legend: R-root hairs B-epidermis H-hypocotyl internode 


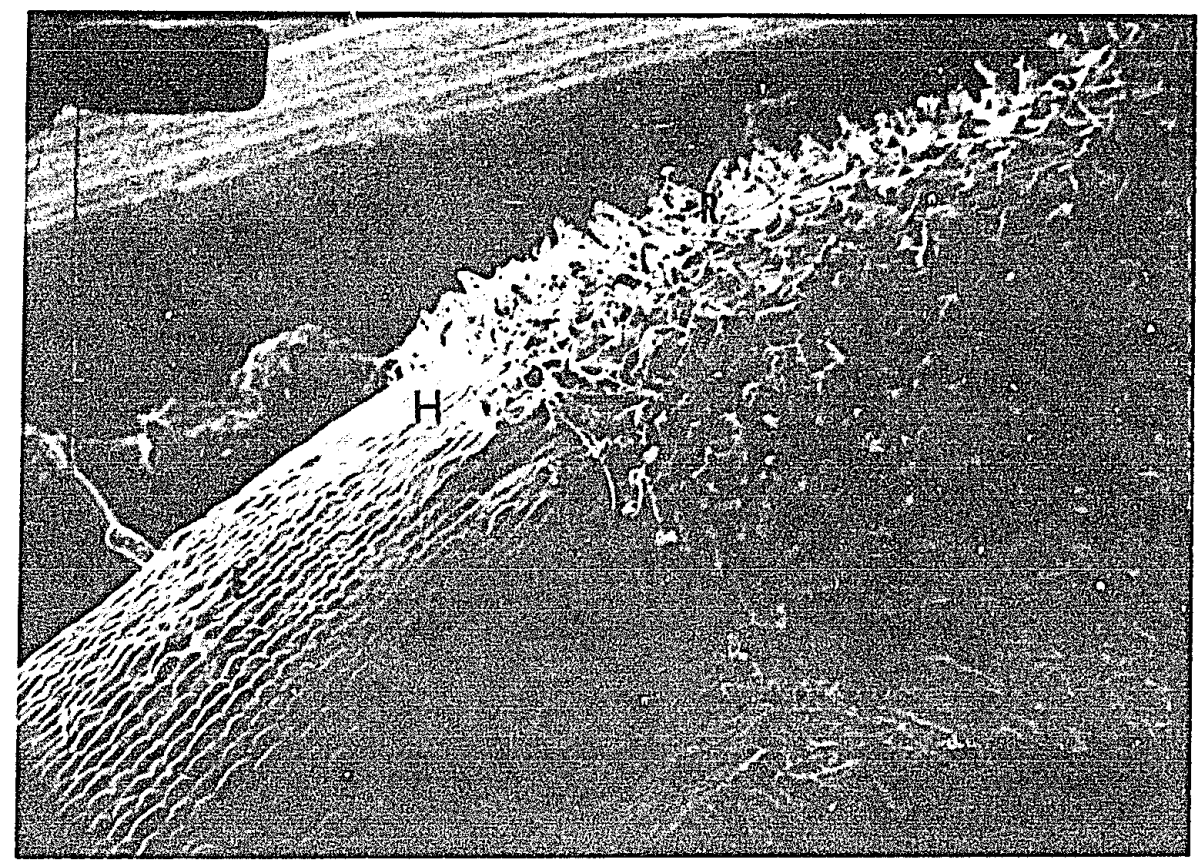

Plate 3. $5 \mathrm{ppm}$ : roots are decreasing in length and appear distorted. The root hairs are becoming twisted and convoluted. 120X Legend: R-root hairs E-epidermis H-hypocotyl internode 


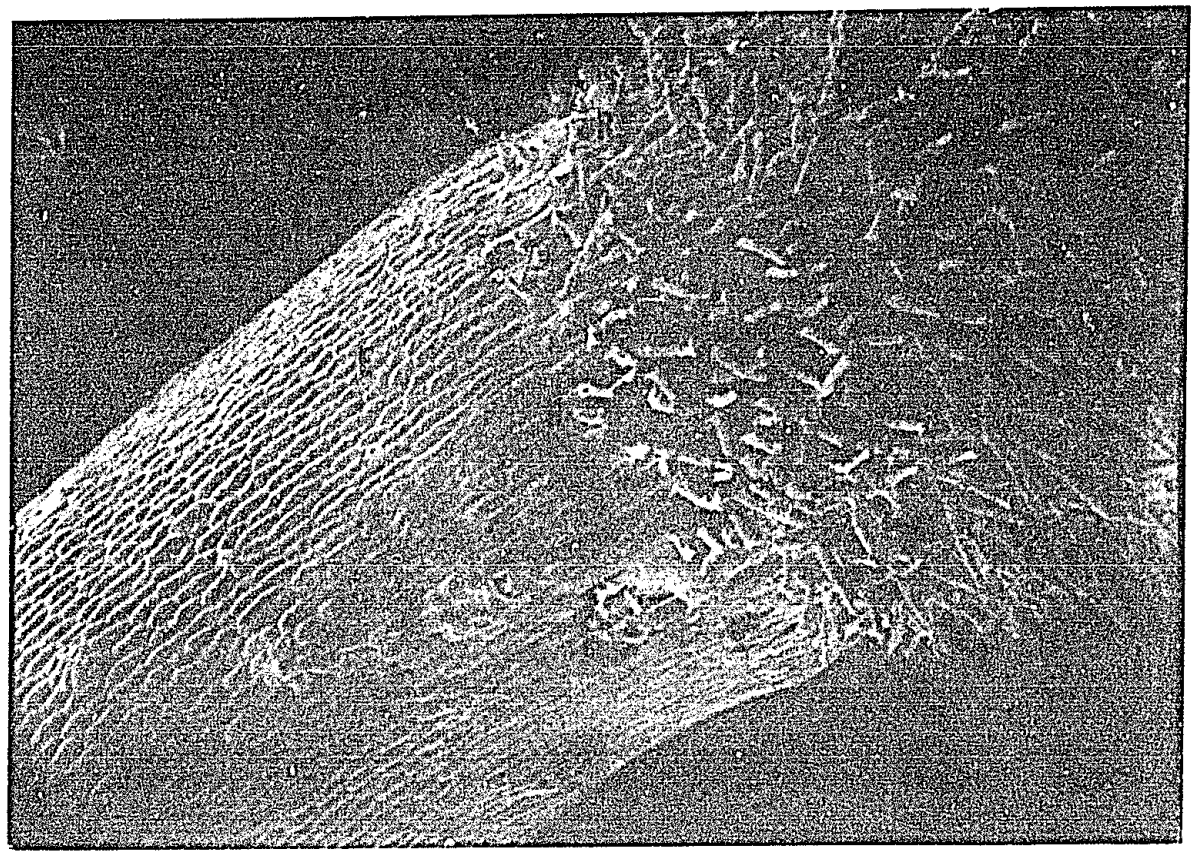

Plate 4. $10 \mathrm{ppm}$ : roots continue to decrease in length and the root hairs continue to show adverse reactions. $114 \mathrm{X}$ Legend: R-root hairs E-epidermis H-hypocotyl internode 


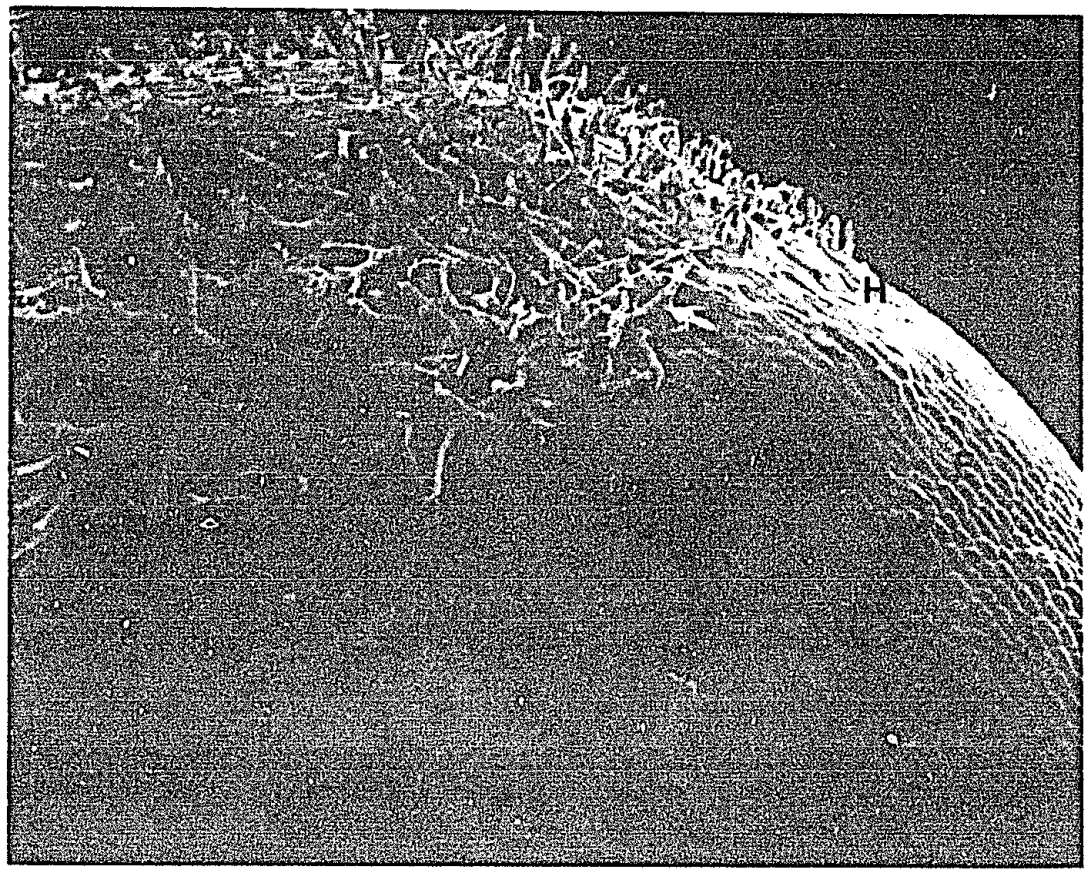

Plate 5. 20 ppm: Primary roots continue to decrease in length and root hairs continue to decrease in length and are becoming stunted.

$114 \mathrm{X}$ Legend: R-root hairs E-epidermis H-hypocotyl internode 


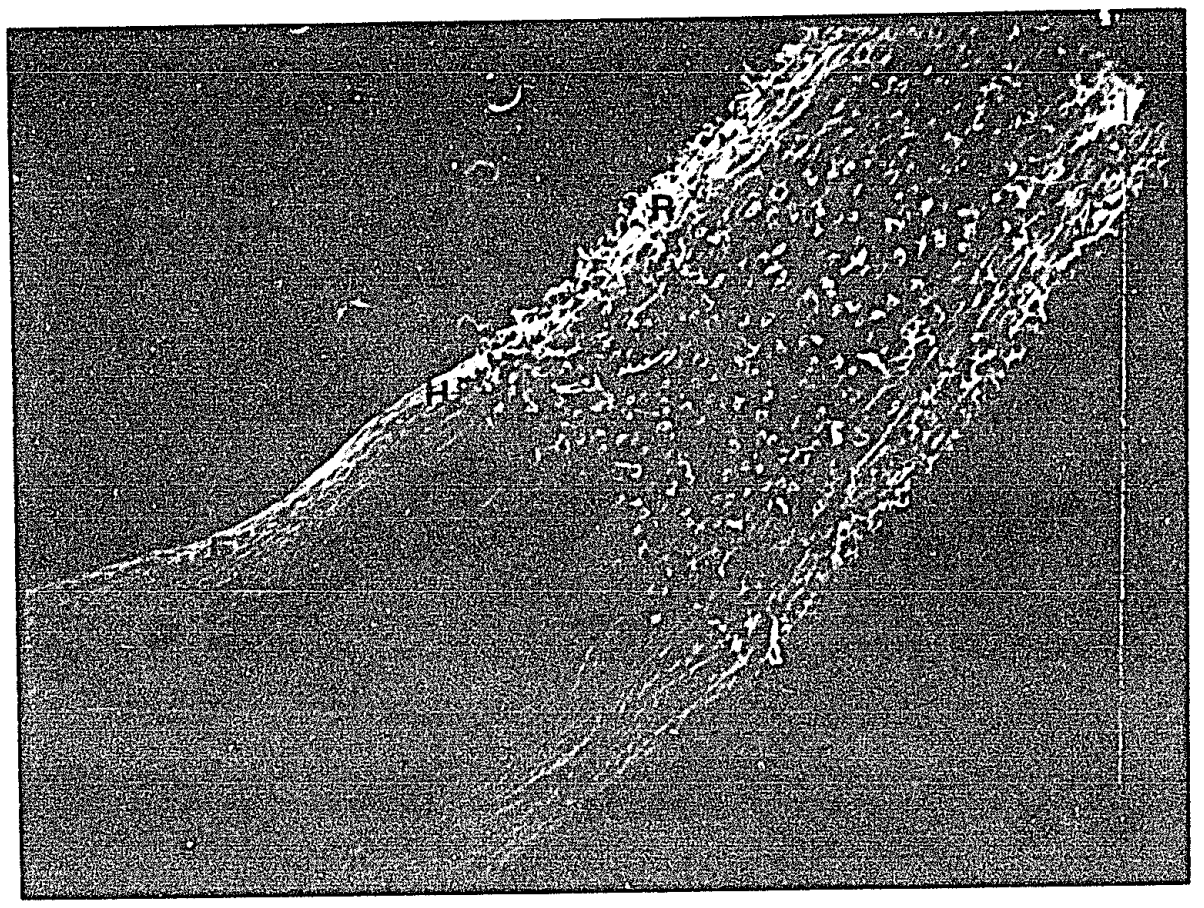

Plate 6. $30 \mathrm{ppm}$ : Primary roots are decreasing in length and the root hairs are exhibiting severe stunting. $80 \mathrm{X}$

Legend: R-root hairs E-epidermis H-hypocotyl internode 


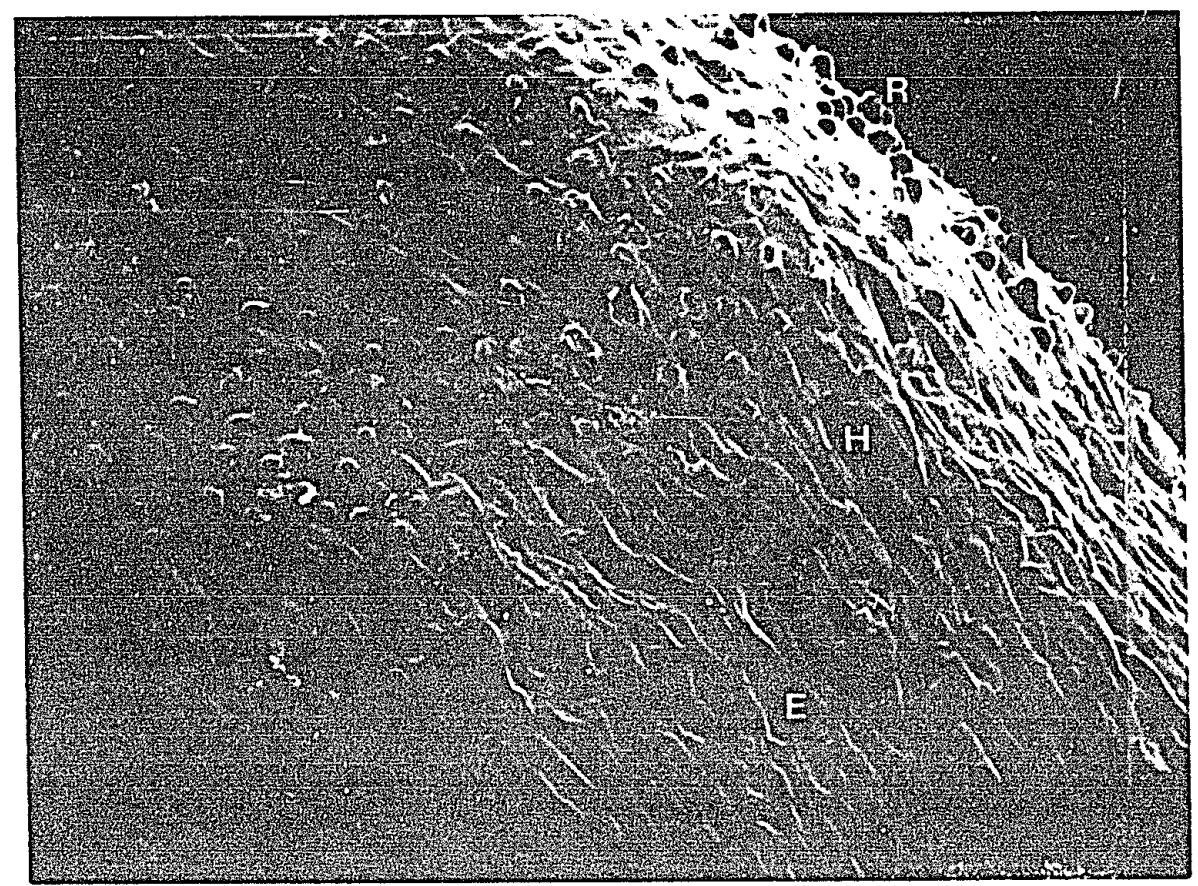

Plate 7. $60 \mathrm{ppm}$ : Primary roots are stunted and the root hairs have become vestigial. The root hairs are barely penetrating beyond the root surface. $160 \mathrm{X}$

Legend: R-root hairs E-epidermis H-hypocotyl internode 


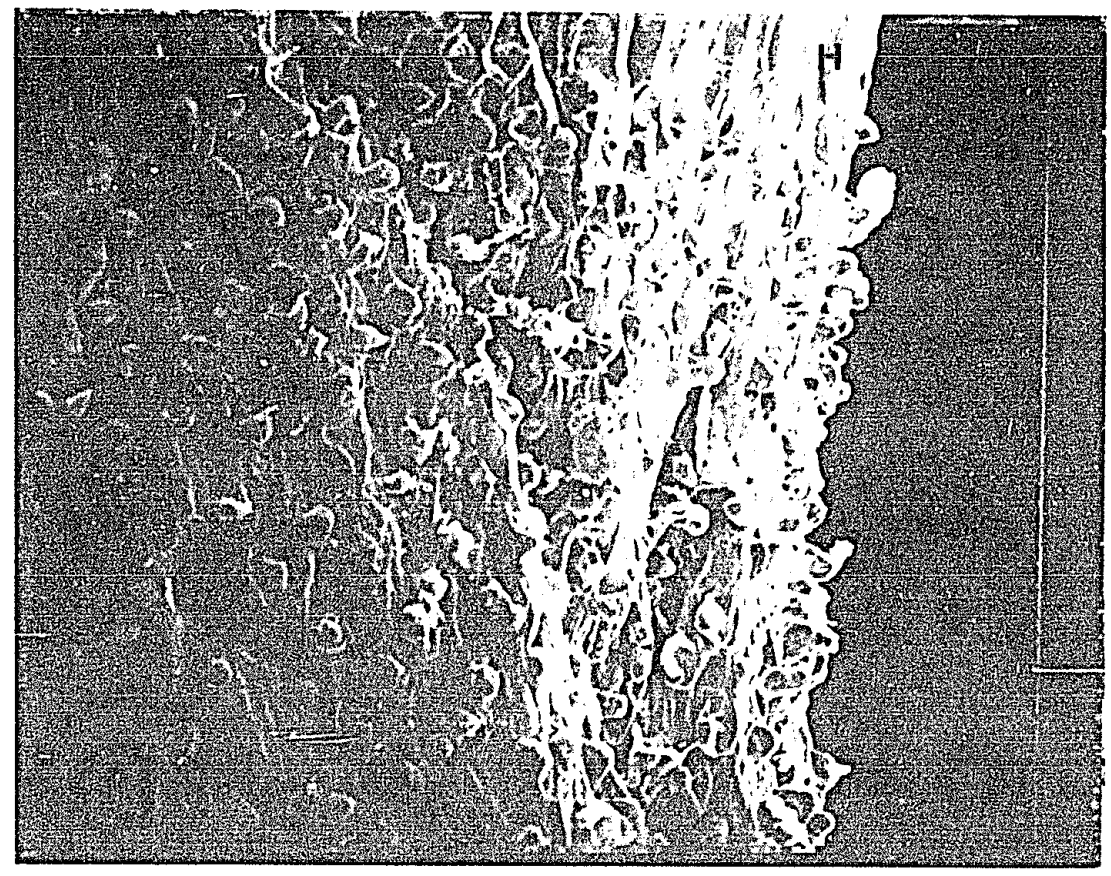

Plate 8. $100 \mathrm{ppm}$ : Primary roots are stunted and the root hairs are vestigial. The root surface is rough and irregular and the epidermal cells are unidentifiable. $280 \mathrm{X}$ Legend: $\mathrm{R}$-root hairs $\mathrm{H}$-hypocotyl internode 


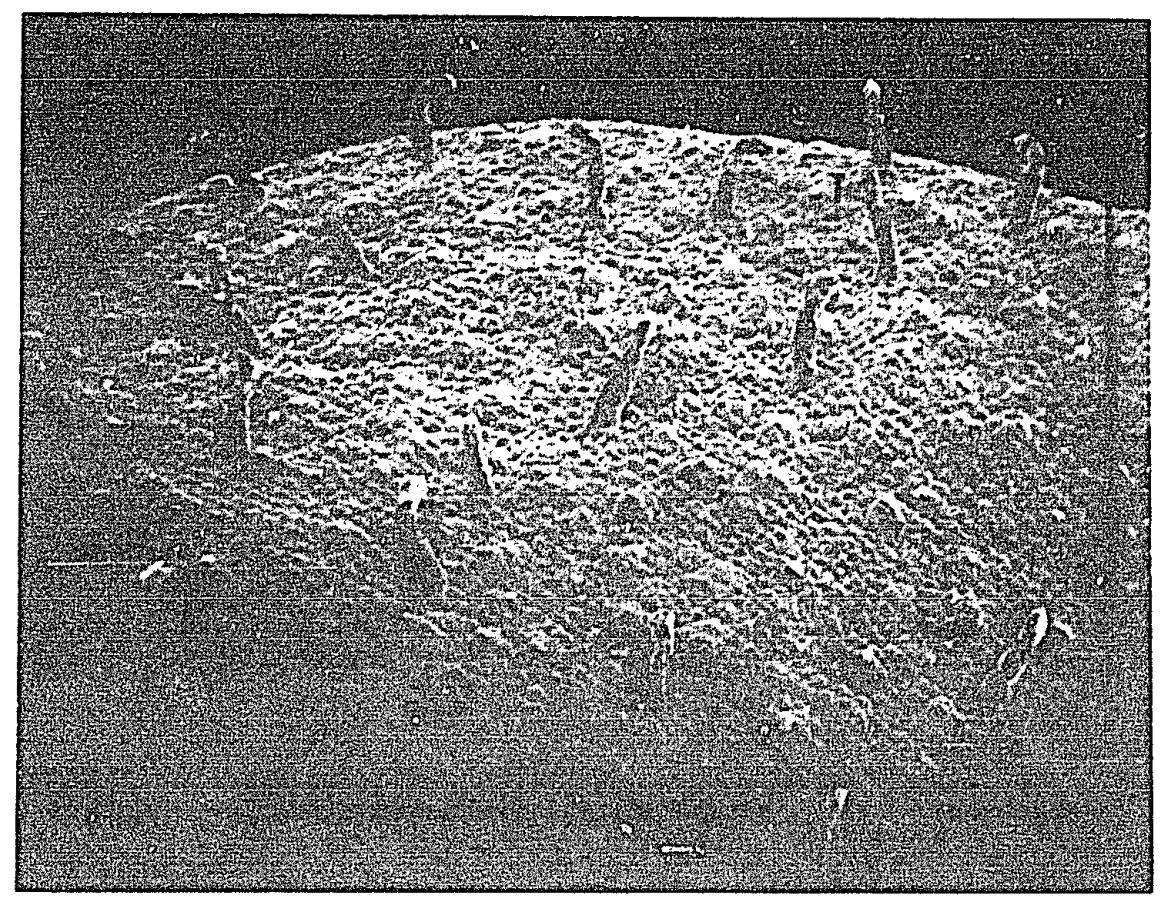

Plate 9. Control $(0 \mathrm{ppm})$ : The cotyledons show normal and evenly distributed stomata as well as normal multicellular capitate trichomes. $80 \mathrm{X}$

Legend: T-trichomes S-stomata 


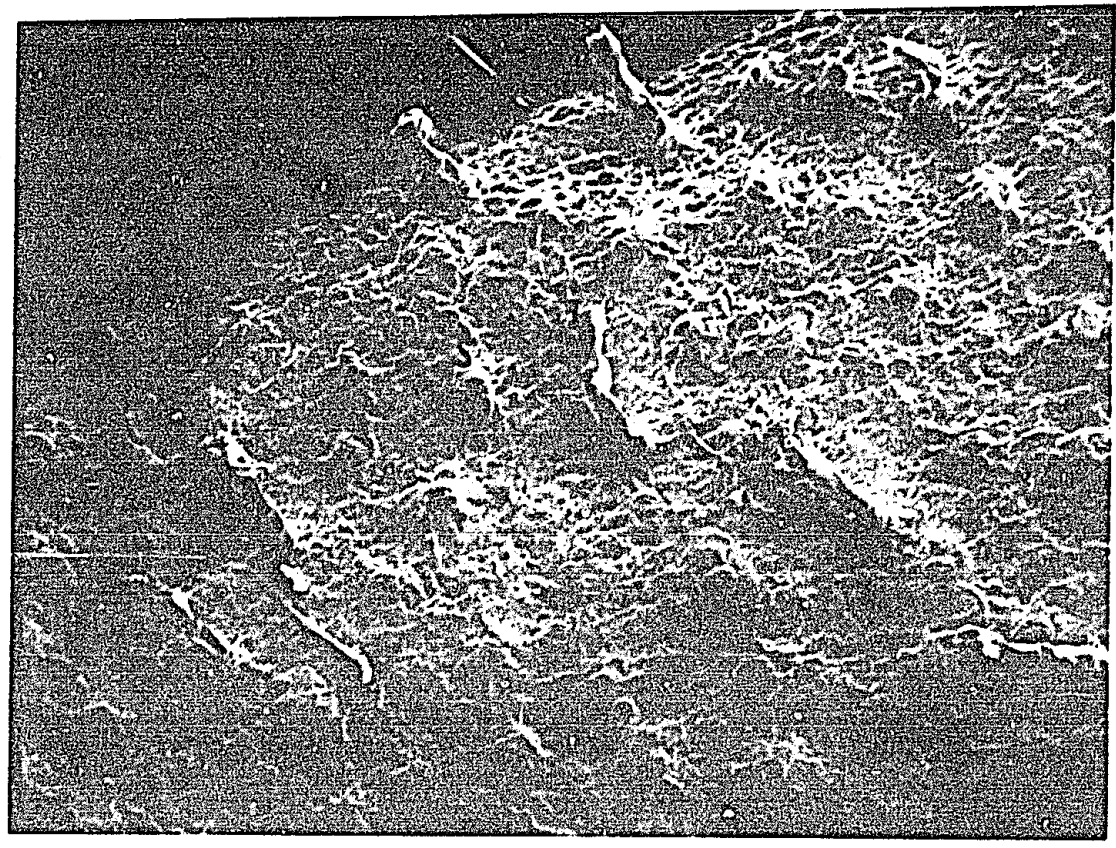

Plate 10. $1 \mathrm{ppm}$ : The cotyledons continue to show normal stomata and capitate trichomes. $160 \mathrm{X}$

Legend: T-trichomes S-stomata 


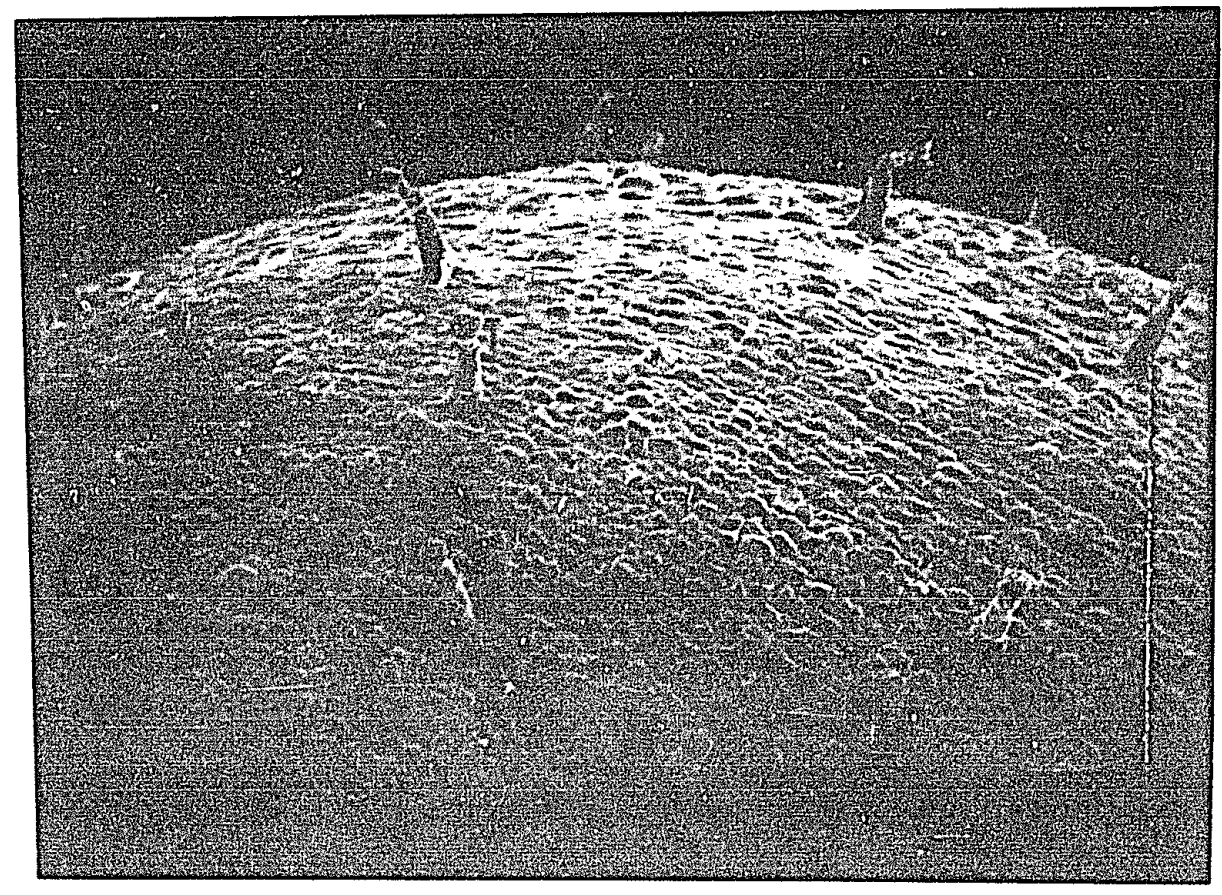

Plate 11. $5 \mathrm{ppm}$ : The cotyledons appear unchanged from the control and continue to show normal stomata and capitate trichomes. $80 \mathrm{X}$ Legend: T-trichomes S-stomata 


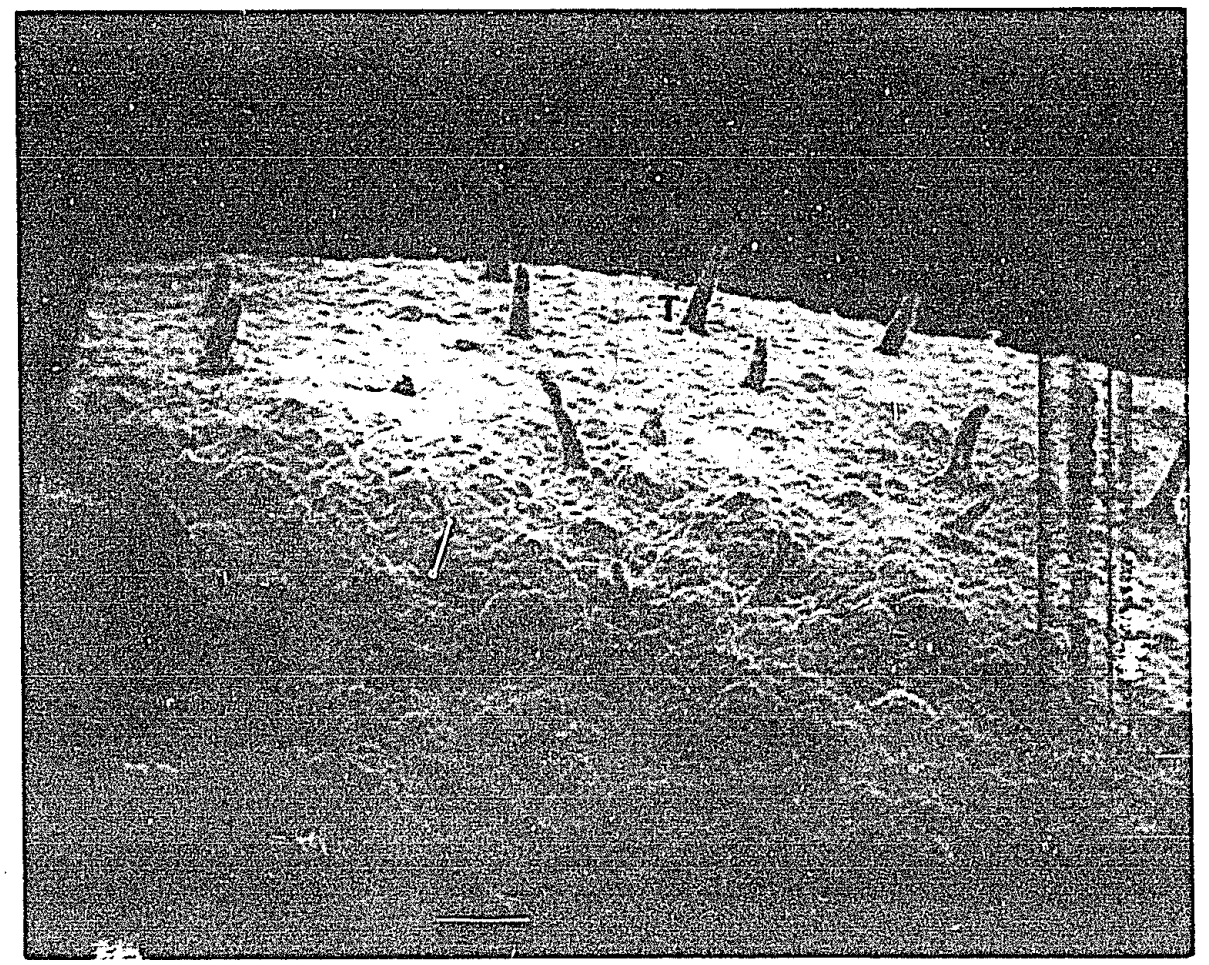

Plate 12. $10 \mathrm{ppm}$ : The cotyledons begin to show effects of increasing zinc concentrations. The cotyledon surface becomes rough in appearance and the capitate trichomes have become stunted. 80X Legend: T-trichomes S-stomata 


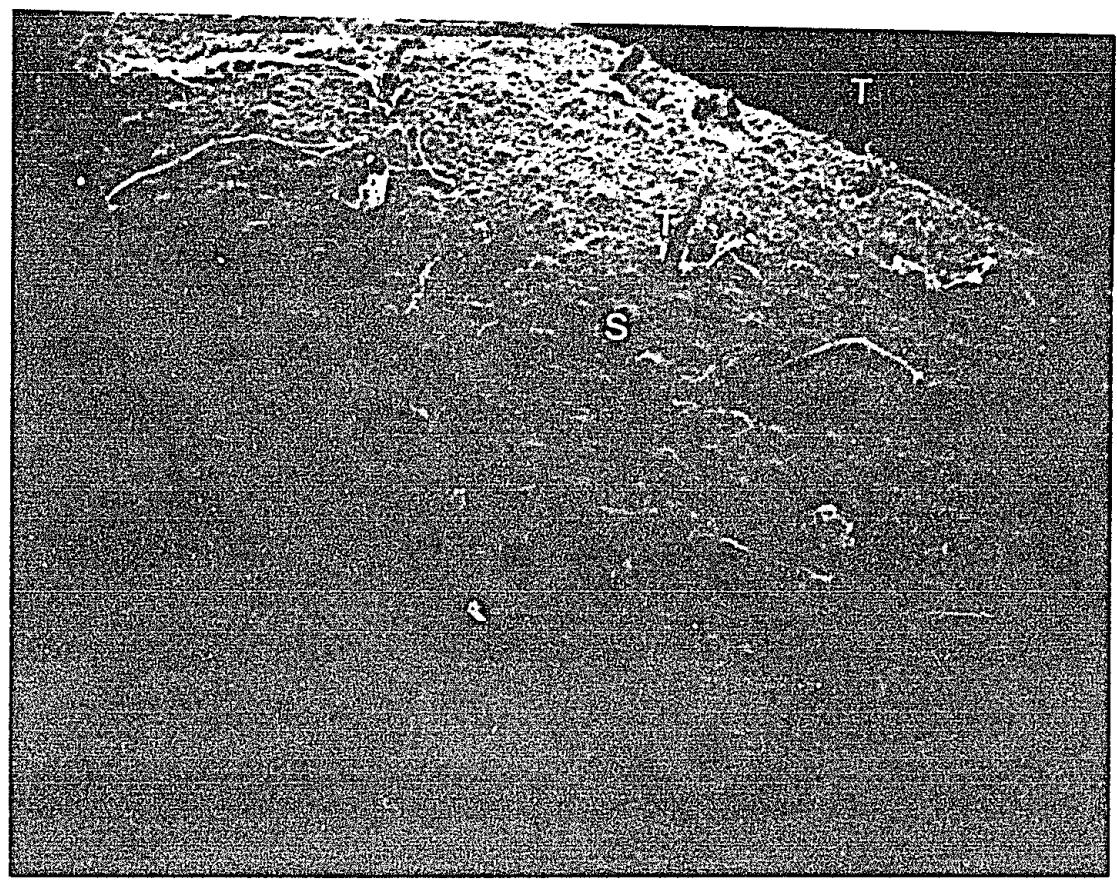

Plate 13. 20 ppm: The cotyledons are continuing to exhibit the adverse effects of increasing zinc concentrations. The guard cells of the stomata appear swollen and elevated from the cotyledon surface. 90X Legend: T-trichome S-stomata 


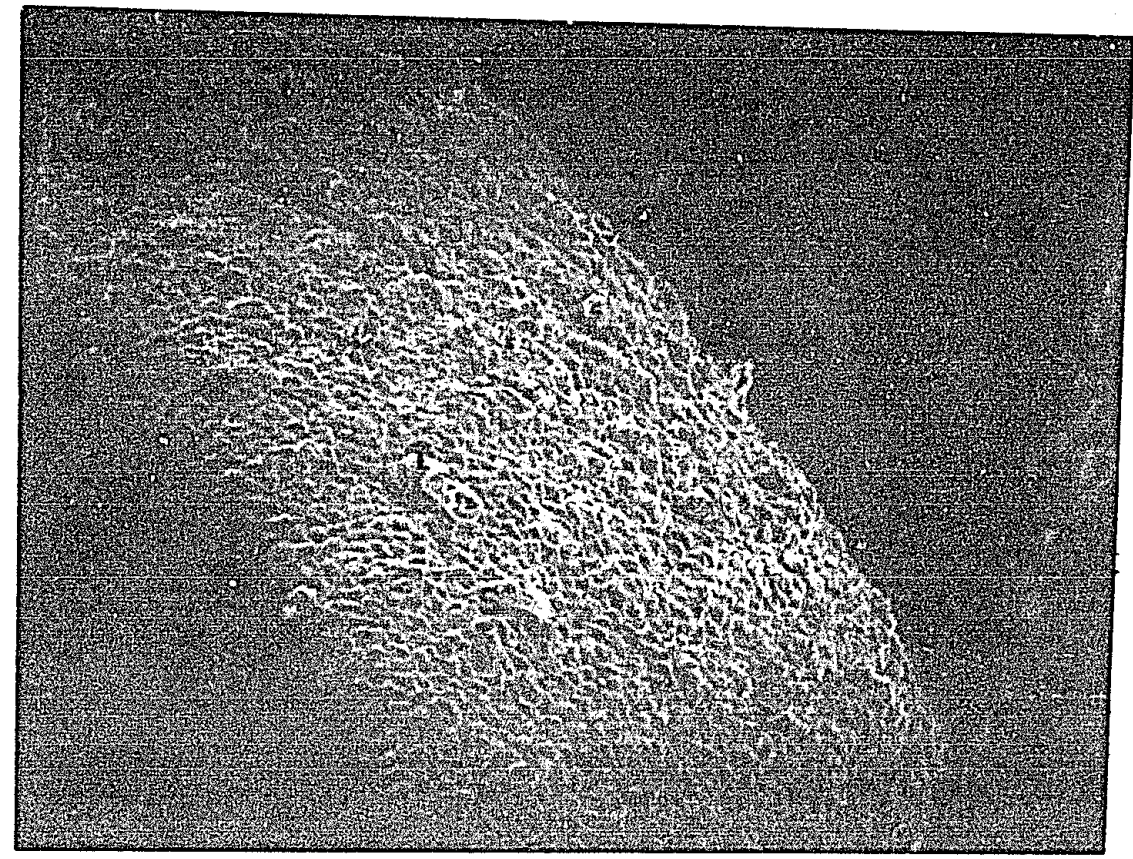

Plate 14. $30 \mathrm{ppm}$ : The cotyledon surface has become rough in appearance and the capitate trichomes have nearly disappeared. The stomata appear less frequently. $160 \mathrm{X}$

Legend: T-trichomes S-stomata 


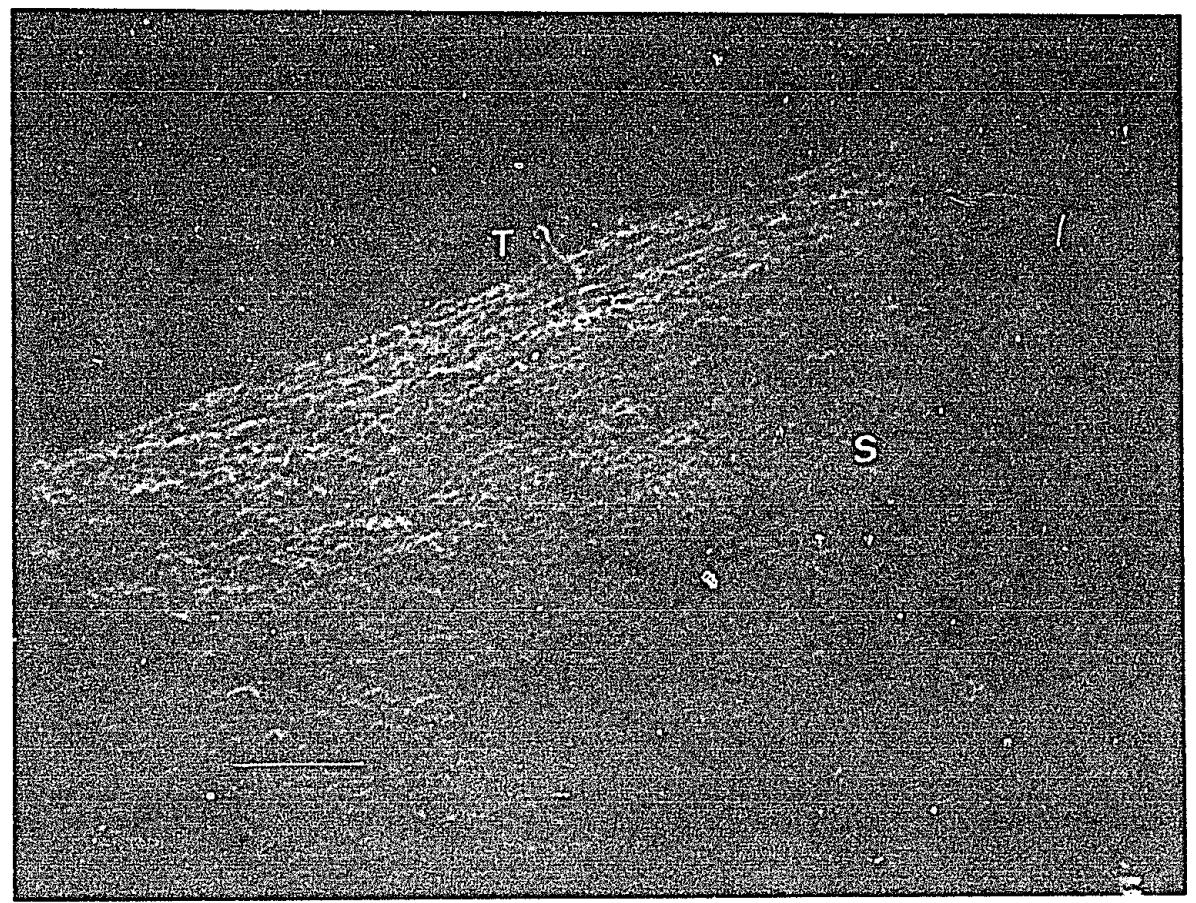

Plate 15. $60 \mathrm{ppm}$ : The cotyledons continue to exhibit the adverse effects of increasing zinc concentrations. The surface is rough and the capitate trichomes have become vestigial. $80 \mathrm{X}$

Legend: T-trichomes S-stomata 


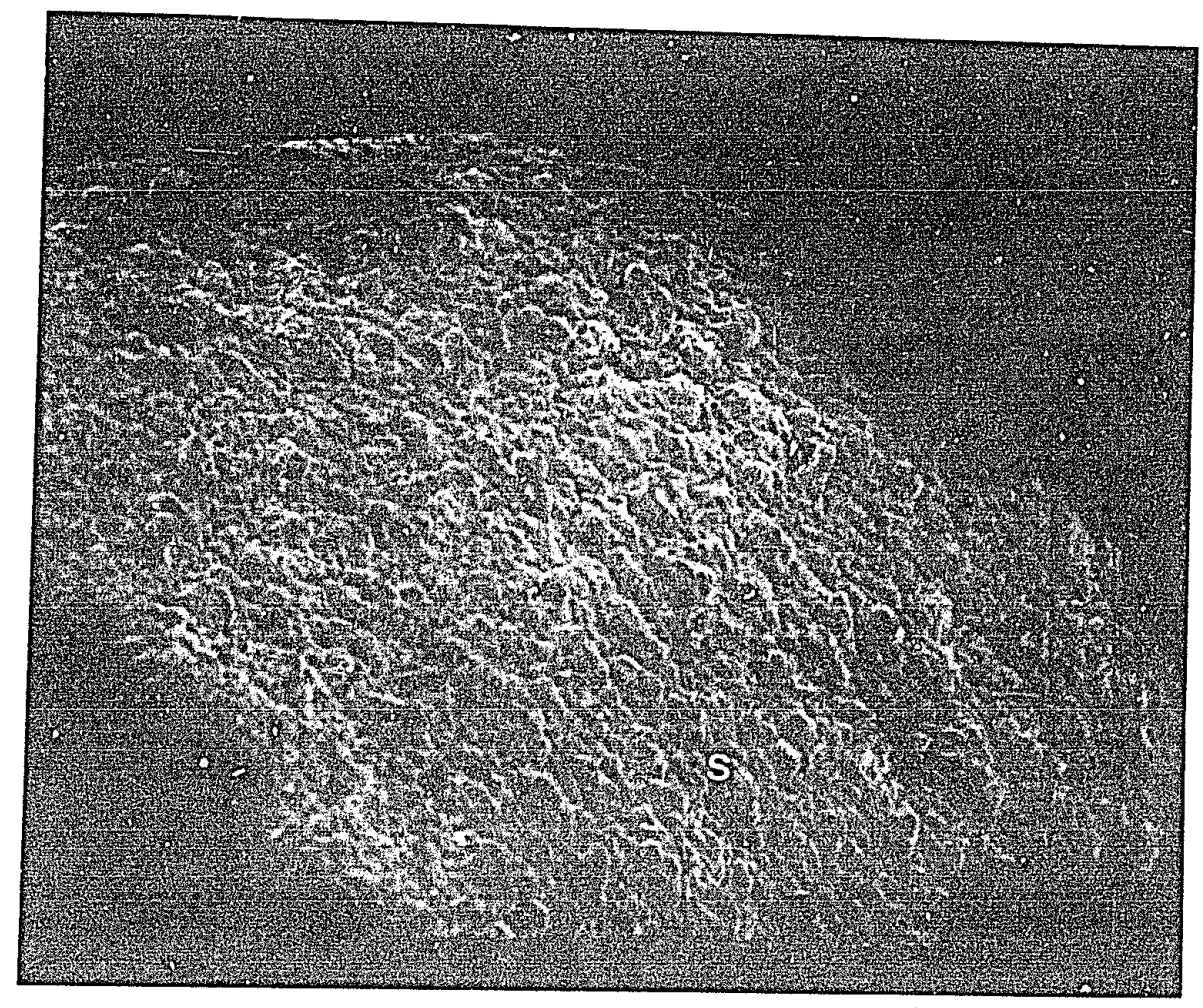

Plate 16. $100 \mathrm{ppm}$ : The cotyledon surface has become so rough in appearance that surface structures are unidentifiable. The capitate trichomes are non-existent and the stomata are difficult to identify. $160 \mathrm{X}$ Logend: S-stomata 


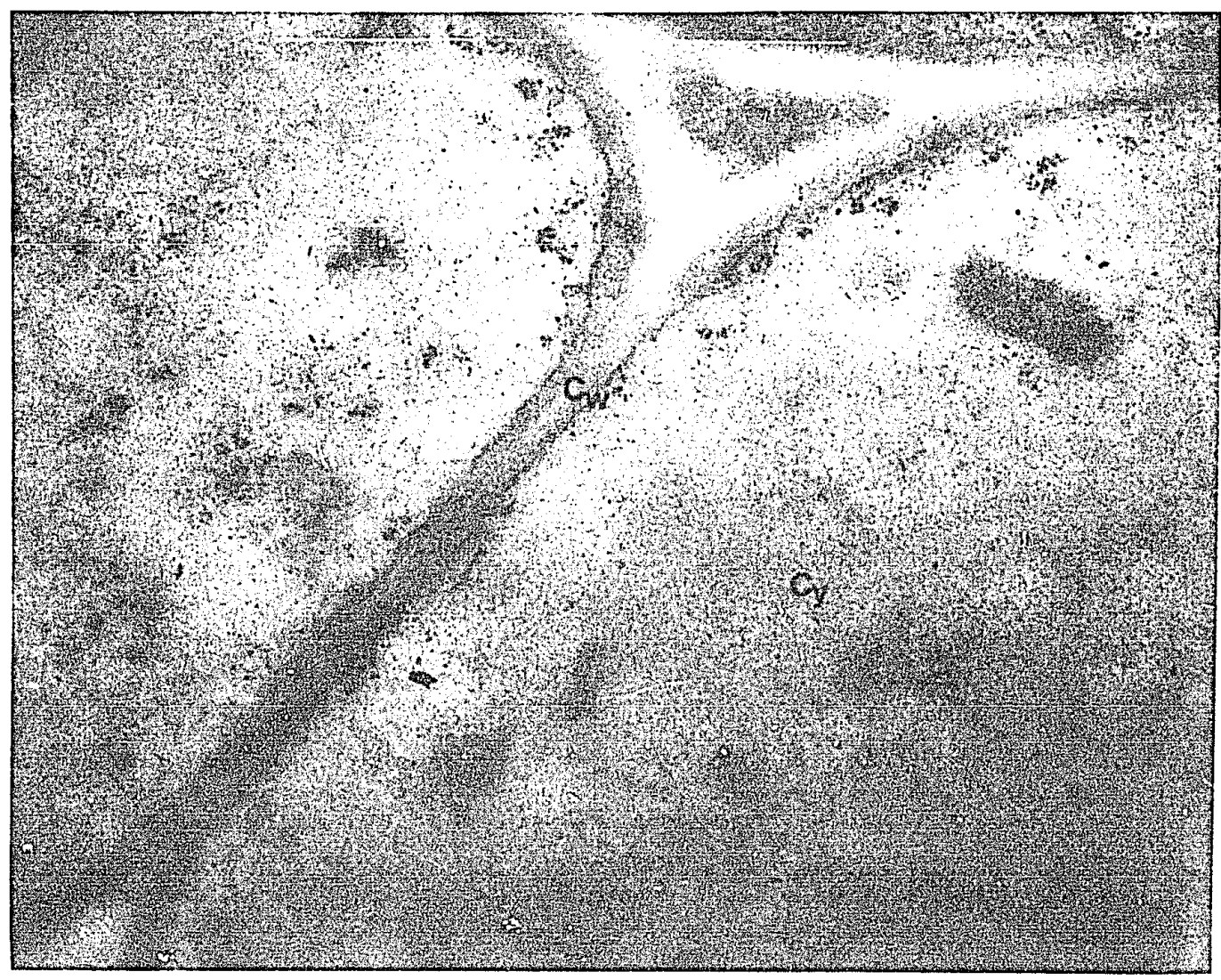

Plate 17. Control $(0 \mathrm{ppm})$ : The cells show the lack of electron dense material in the cytoplasm. The cell walls appear regular and unpitted. Legend: Cy: cytoplasm Cw: cell wall 12000X 


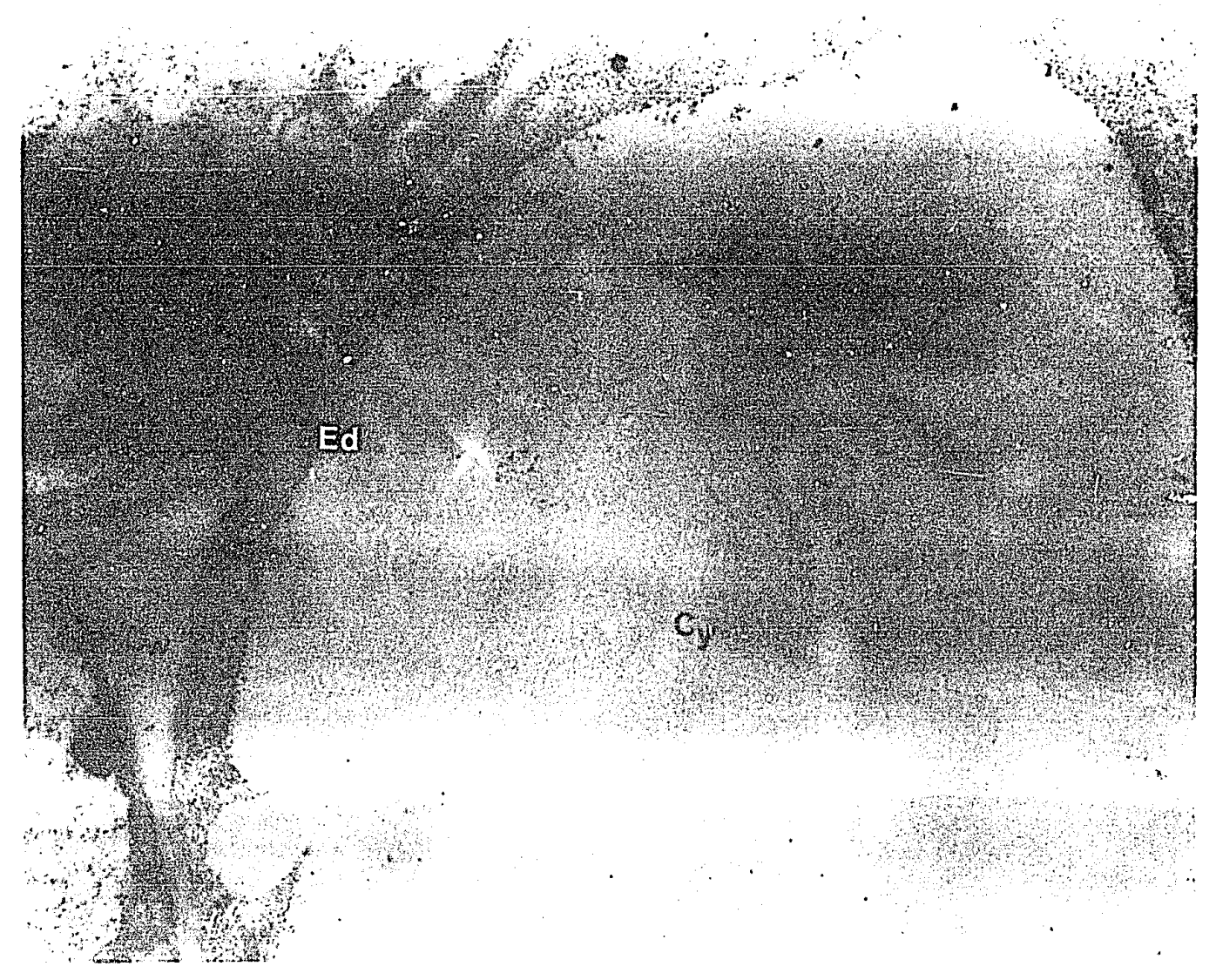

Plate 18: $5 \mathrm{ppm}$ : The cell walls show the appearance of electron dense material. This appears to be the site of deposition rather than the cytoplasm. Legend Cy: cytoplasm Cw: cell wall Ed: electron dense material $20000 \mathrm{X}$ 


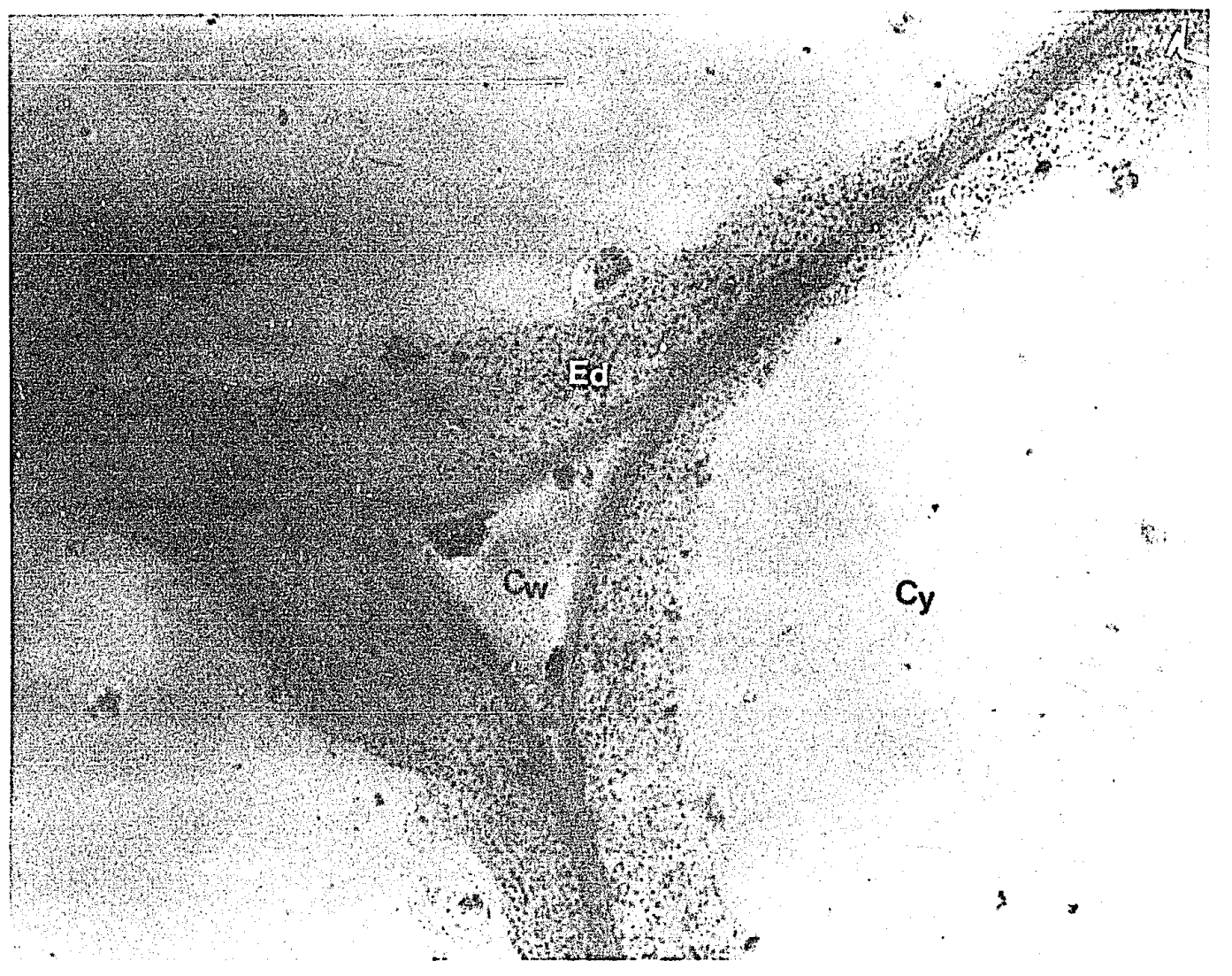

Plate 19: 20 ppm: The cell walls show the appearance of electron dense material. The cell walls also show an irregular shape.

Legend: Cy: cytoplasm Cw: cell wall Ed: electron dense material $7000 \mathrm{X}$ 


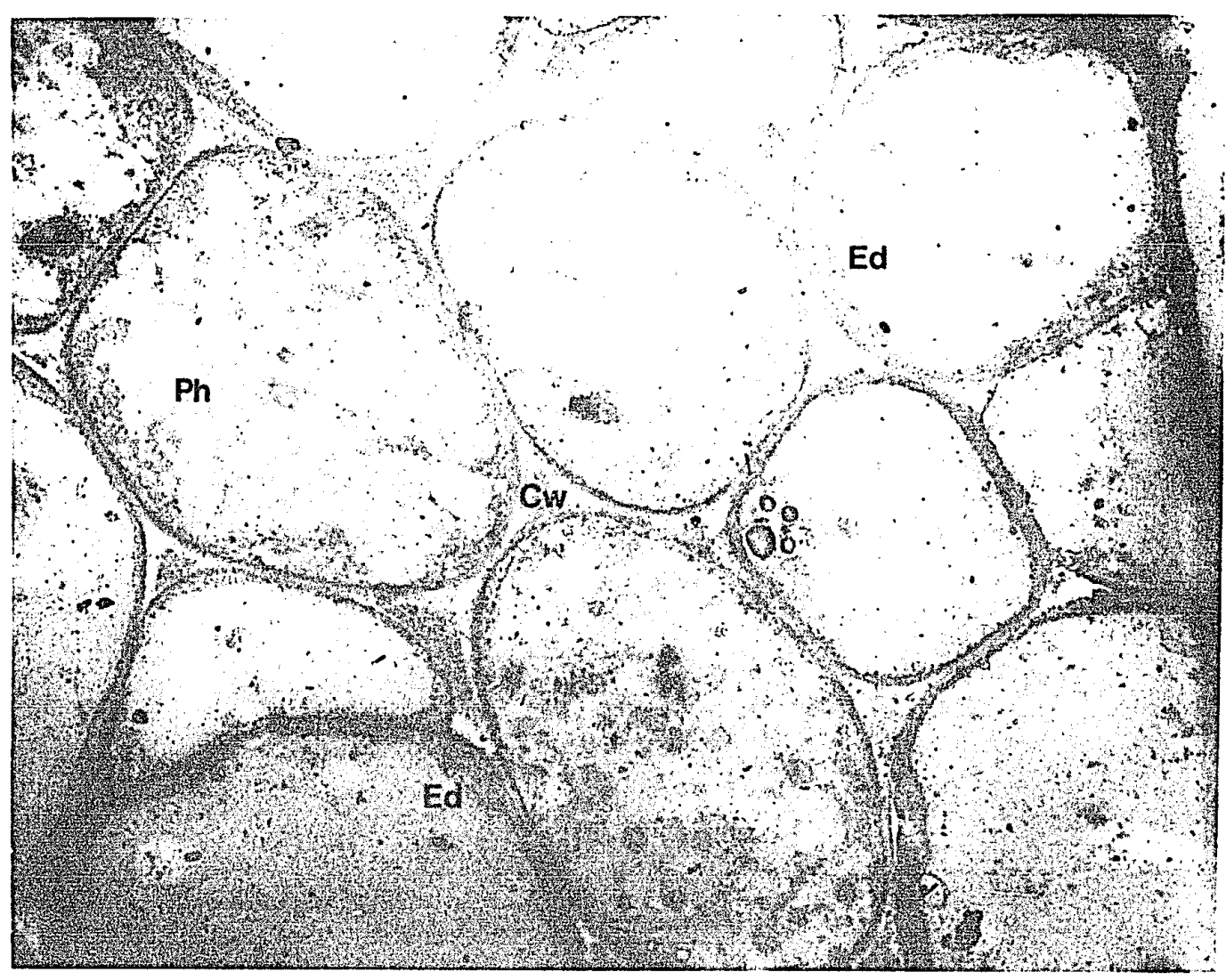

Plate 20: Control (0 ppm): This photograph contains vascular tissue and surrounding cells. The vascular cells show the presence of electron dense material but not that from the presence of zinc concentrations. Legend:Ph: phloem Cw: cell wall Ed: electron dense material $3000 \mathrm{X}$ 


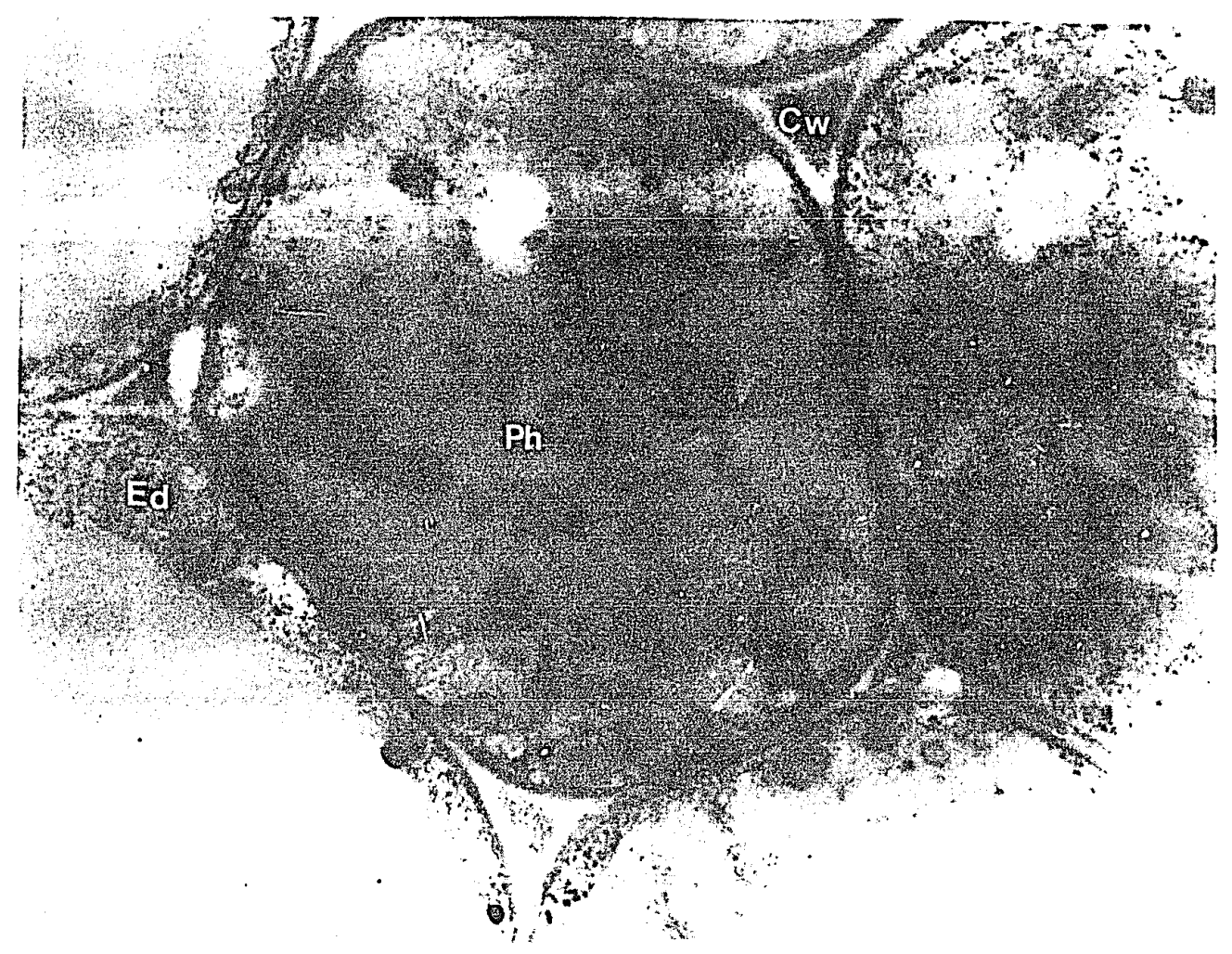

Plate 21: $5 \mathrm{ppm}$ : The photograph contains vascular tissue and surrounding cells. The vascular cell contains electron dense material that may be associated with zinc concentrations. The adjacent cell shows the deposition of electron dense material along the cell wall. Legend: Ph: phloem Cw: cell wall Ed: electron dense material $7000 \mathrm{X}$ 


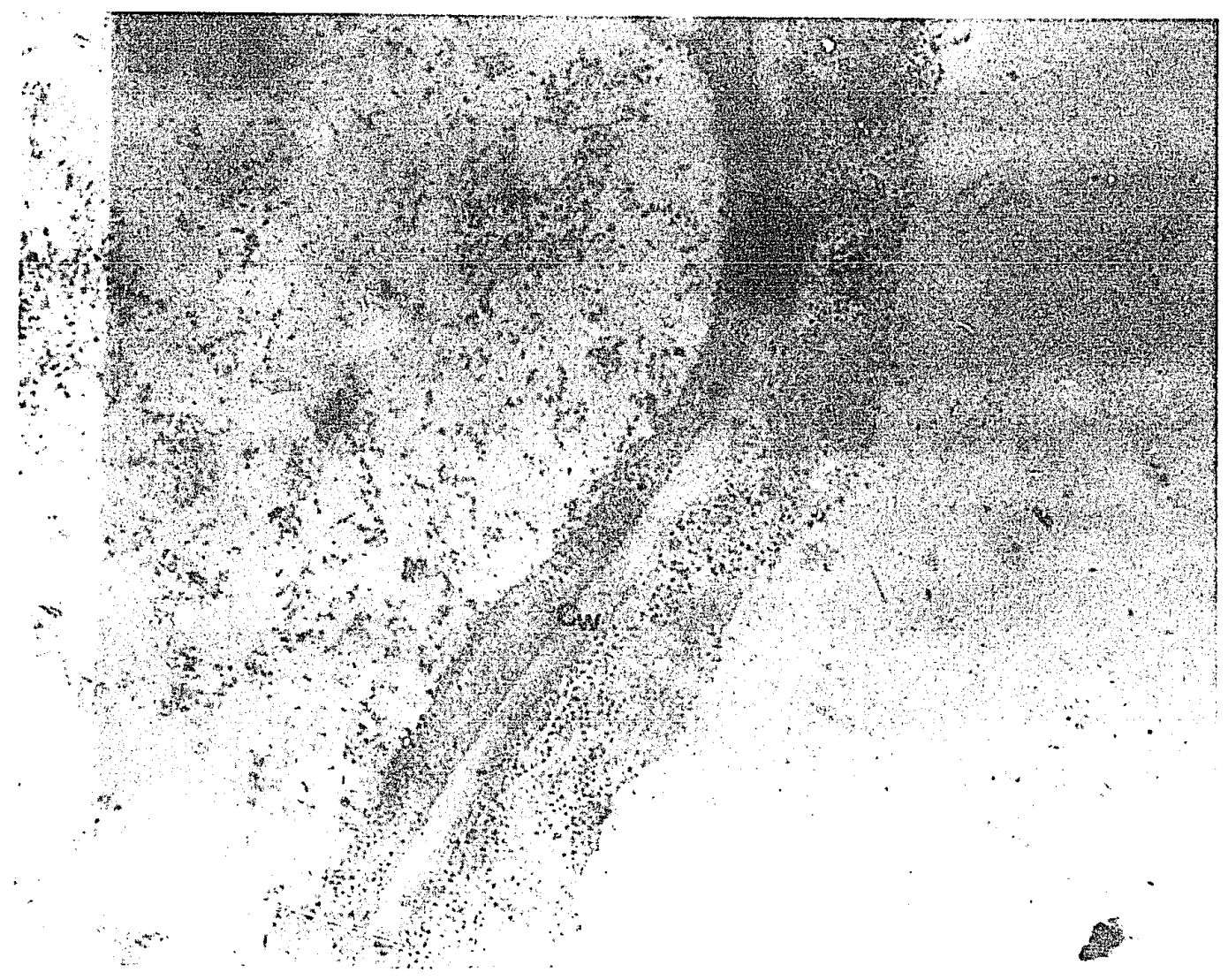

Plate 22: $5 \mathrm{ppm}$ : The photograph shows the presence of electron dense material located along the cell wall. The cell wall also shows the beginnings of an irregular appearance. The cell walls have started to become pitted. Legend: Cw: cell wall Ed: electron dense material (arrows show pits) $12000 \mathrm{X}$ 


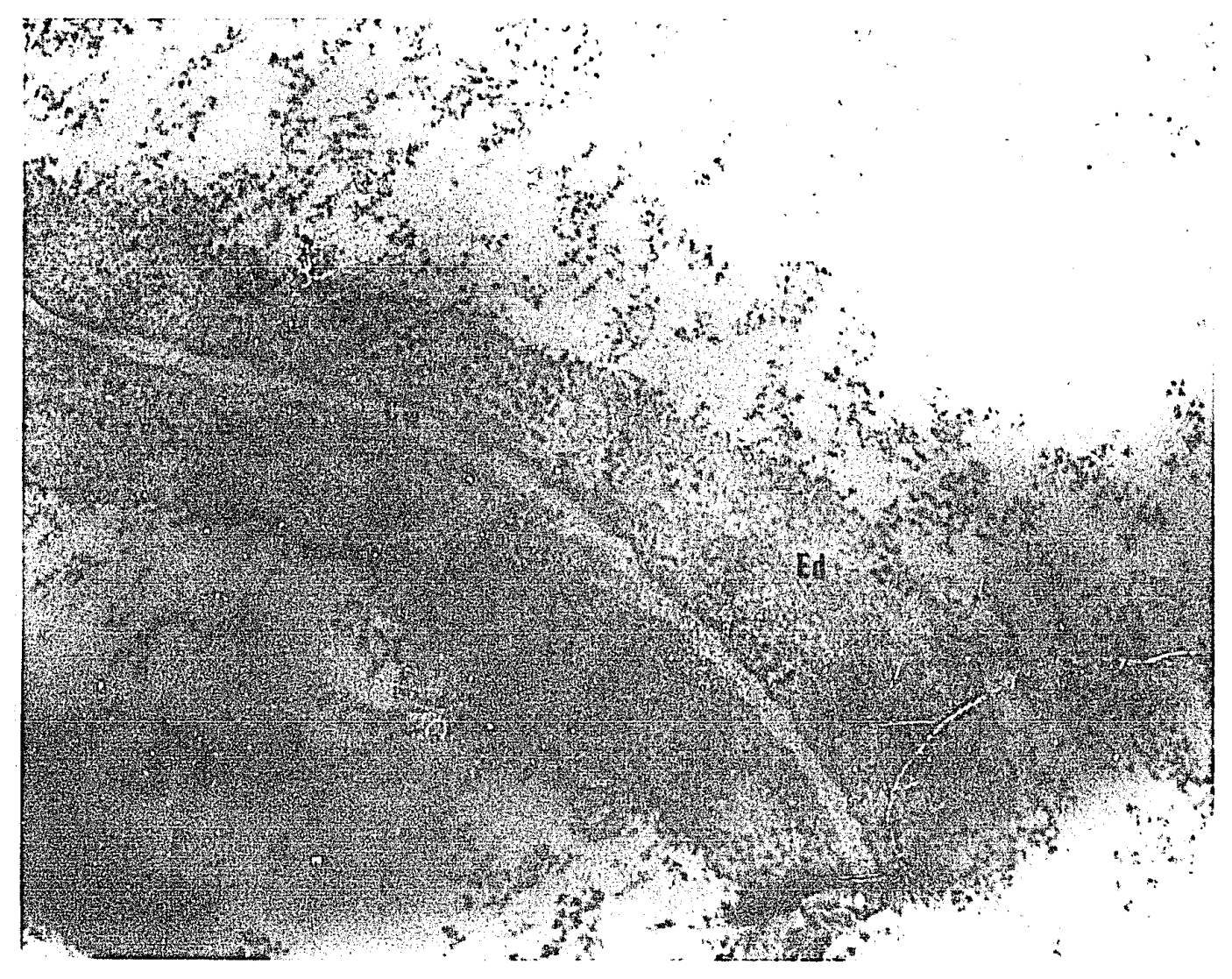

Plate 23: $20 \mathrm{ppm}$ : The photograph shows the greater presence of electron dense material compared to plate 22 . The cell walls are also exhibiting more irregular and pitted appearance. Legend: $\mathrm{Cw}$ : cell wall Ed: electron dense material ( arrows show pits) $12000 \mathrm{X}$ 


\section{DISCUSSION}

The effects of increasing concentrations of zinc become readily visible at $10 \mathrm{ppm}$ where there is a significant reduction in root length. The average root length of the first three treatment levels remained constant and varied little. The average length ranged from $36.59 \mathrm{~mm}$ to $34.65 \mathrm{~mm}$ (table 2). However at $10 \mathrm{ppm}$, a significant change occurred. The average root length decreased to $26.29 \mathrm{~mm}$, a change of $-28 \%$. The statistical analysis of the data showed that there was no significant difference between the first three treatments but that a significant change appeared at $10 \mathrm{ppm}$ (tables 2 and 3 ). Berry (1977) found that increasing the concentration of zinc above the plants toxic threshold resulted in a proportionate decrease in root growth. It was evident that developing lettuce seedlings have a tozic threshold (in solution) located between 5.0 and $10.0 \mathrm{ppm}$ zinc and that exceeding this level resulted in a decrease in root growth. The acute threshold is that concentration of the metal which first limits growth on shori exposure. Berry also found that the root length was reduced to $1 / 2$ that of the control by concentrations of 115 micro/equiv per liter zinc, and that a toxic threshold occurred at 66 micro/equiv/L.

Davis and Beckett (1978) found that the onset of zinc tozicity in barley (Hordeum vulgare) occurred at $8.3 \mathrm{ppm}$ zinc in solution. They measured the change in total dry weight of the plant rather than changes in morphology. This corresponded to the onset of observable changes found in root lengths in this study. Godbold and Huttermann (1985) found that zinc inhibited root elongation in spruce (Picen abies) seedlings. They found that root elongation was greatly inhibited by 30 and $60 \mu \mathrm{m}$ zinc but that 5 and $15 \mu \mathrm{m}$ zinc had no 
detectable inhibition on root elongation. Brown and Wilkins (1985) found that growth in Betula spp was reduced by zinc treatments. In another study by these authors (1986), zinc affected both hypocotyl and radical elongation in Betula spp. As the toric level increased, they found that neither hypocotyl or radicle growth could be sustained. This was similar to the effects of increasing concentration of zinc found in this study. As the zinc concentration reached and exceeded $60 \mathrm{ppm}$, the overall length of the root remained relatively unchanged ( figure 1 ).

$\mathrm{Nag}$, et al. (1984) found that the appliction of $\mathrm{ZnSO}_{4}$ inhibited both the shoot and root length of rice (Oryza sativa) and that the inhibition increased with increasing concentrations of the metal. At $10 \mathrm{mM}$, the inhibition of the roots was $80 \%$ from the control and that root growth was almost completely inhibited at $40 \mathrm{mM}$. The authors found that they could reduce the zinc induced inhibition of the root with the application of gibberellic acid $\left(\mathrm{GA}_{3}\right)$. In addition, the authors found that the application of zinc promoted the activity of IAA oxidase and inhibited the formation of IAA synthetase. This caused an inhibition of growth from the resultant decrease in IAA concentration.

Other authors have found similar effects of zinc on plant growth. Rauser (1973) found that zinc reduced growth in seedlings of beans (Phaseolus vulgaris), soybeans (Glycine max), and corn (Zea mays). Patel, et al. (1976) found that chrysanthemums (Chrysanthemum morifolum) exhibited a $21 \%$ reduction in growth at $10^{-4} \mathrm{M}$ of zinc. Veltrup (1978) examined zinc uptake by barley roots (Hordeum distichon) and determined that there were three 
distinct transition periods independent of the tested uptake period. Paivoke (1983) found a decrease in the root length of pea seedlings (Pisum sativum) with increasing zinc concentrations.

The SEM examination of the roots showed that the root hair length and density were affected by increasing zinc concentrations. At 0,1 and $5 \mathrm{ppm}$ zinc the root hair length and density remain relatively unchanged (plates 13). The root hairs are elongated and evenly spaced. At $10 \mathrm{ppm}$ zinc, the density and lengths of root hairs begin to be affected and a definite reduction in the length and density occurs (plate 4). As the concentration of zinc increases, the root hairs become stunted and eventually appear as small nodules (plates 5-8). The root epidermis undergoes a similar transformation. As the concentration increases beyond $10 \mathrm{ppm}$ zinc the epidermis becomes disrupted. Normal epidermal cells are smooth and uniform in appearance, but the increase in toxicity causes these cells to lose their structural integrity. They now appear rough and irregular in shape and at elevated zinc levels, the epidermal cells become lignified.

Paivoke (1983), using light microscopy, examined anatomical changes in pea seedlings ( $\mathrm{P}$. sativum). Paivoke found that in zinc treated roots, the epidermis was lignified and that root hairs were scarce at the $0.01 \mathrm{mM}$ concentration. The radial and tangential walle of the endodermal celle were lignified and a reddish-brown pigment occurred in the cells.

The TEM analysis of the root tissue showed that there was an increase in electron dense material along the cell walls with increasing zinc concentration. It appears that the cell walls undergo changes as well. The cell walls become pitted and appear irregular in shape at $20 \mathrm{ppm}$ zinc. Robb, et al 
(1980) using TEM, examined white beans (Bhaseolus vulgaris) exposed to excessive zinc. Their examination of xylem vessels showed gelation of the pit membranes and deposition of electron-dense material in the secondary vessel walls. The rylem tissue was obtained from leaves, unlike the root tissue examined in this study. However, there are similarities in results between both studies. Both studies found deposition of electron-dense materials and alterations of cell walls.

Turner, et al. (1971) found localization of $65 \mathrm{Zn}$ in the cell wall fraction from root tissue of Agrostis tenuis. This would correlate with the evidence found by TEM examination of the electron dense material located along the cell wall.

The root cap showed a decline in length when the zinc concentration exceeded $10 \mathrm{ppm}$. This is slightly higher than the acute threshold found for the entire root. However, the difference in expressed toxicity may result from the type of cells comprising the root cap.

The primordia density (graph 5) shows an interesting pattern. There is an initial decline in numbers and then at $10 \mathrm{ppm}$ zinc, there is an increase followed by a decline. This could be a result of a lag period for acute tozicity to manifest itself on the primordia. Prior to $10 \mathrm{ppm} z i n c$, the roots exhibit stimulation that manifests as an increase in secondary root numbers and length. At $10 \mathrm{ppm}$ zinc, the root length exhibits the adverse effects of the zinc concentration. However, the primordia numbers appear to be increased. At $20 \mathrm{ppm}$ zinc, the primordia numbers decrease by $46 \%$ (5.24 to 2.84 ). Perhaps an explanation lies in understanding root primordia development. Divisions in the pericycle are responsible for primordia development, but 
these occur beyond the region of elongation (Raven, et al. 1976). As zinc levels increase in the root and begin to have a toxic influence at a level below $10 \mathrm{ppm}$, root elongation is affected. The primordia initially are unaffected because of their location relative to the region of elongation. However, as the zinc levels increase and zinc is deposited in greater number of cells, the metal begins to exert a toxic influence on a wider range of structures and plant function.

The cotyledons were measured for surface area and changes in surface area resulting from increasing zinc levels since a measurement of surface area would be more significant than length or width. A plant may exhibit changes in leaf length or width, but if the relative surface area is unchanged, then the plants photosynthetic structures and metabolic functions such as transpiration may be less affected. The cotyledons had a shape that best fit an ellipse and that the surface area could be determined by using that formula. The value obtained was then doubled to give total surface area (both surfaces).

Examination of figure 4 reveals that there is an initial stimulation of cotyledon surface area at $5 \mathrm{ppm}$ zinc, followed by a decline. Zinc is primary for growth and can stimulate growth at levels below the toxic threshold. Berry (1971) determined the nutrient status of zinc in developing seedlings. He based his findings on fresh weight. He found that there was an initial increase in yields above the determined level of deficiency.

As the concentration of zinc increases beyond $5 \mathrm{ppm}$, there is a steady decline in cotyledon surface area. From an average area of $33.52 \mathrm{~mm}^{2}$ at 5 $\mathrm{ppm}$, there is a decline of $39 \%$ to $20.56 \mathrm{~mm}^{2}$ at $100 \mathrm{ppm}$ zinc. 
Figure 6 (eophyll length) illustrates a stimulation of growth at $5 \mathrm{ppm}$ zinc and then a subsequent decline. There is a change in length from a high of $1.41 \mathrm{~mm}$ at $5 \mathrm{ppm}$ to $0.29 \mathrm{~mm}$ at $100 \mathrm{ppm}$ zinc. This change is comparable to the results found for cotyledons.

Nag, et al. (1984) found that zinc caused a decrease in shoot growth in rice (Oryza sativa) when exposed to $10 \mathrm{mM}$ or more of $\mathrm{ZnSO}$. They found a decline of $56 \%$ in shoot fresh weight at $40 \mathrm{mM}$ of zinc. Davis, et al. (1978) found a decline in dry weight of ryegrass (Lolium perenne) and barley (Hordeum) with increased levels of zinc. Other researchers have found similar effects of zinc toxicity on plant yields (Ohki, 1975; Patel, et al. 1976; Wallace, 1982; Paivoke, 1983).

The SEM examination of the cotyledons reveals some interesting changes. Plates 9-11 show little variation in surface structures. The stomata and capitate trichomes appear unchanged. However, at $10 \mathrm{ppm}$ zinc (plate 12) the cotyledons begin to exhibit changes related to zinc toxicity. The most obvious manifestation is the stunting of the trichomes and the appearance of rough surface texture. Plates $12-16$ also reveal that there is a decrease in numbers of stomata and that they appear elevated above the epidermis. Savage, et al. (1981) found that copper produced similar results to cotyledons of treated lettuce seedlings.

The results of this study have shown that zinc stimulated growth at low doses, but as zinc levels increased beyond the toxic threshold, near $10 \mathrm{ppm}$, deleterious effects begin to be ezhibited.

At levels below $10 \mathrm{ppm}$, zinc stimulated primary root growth, oxcurrence of secondary roots and the integrity of root epidermal cells. The cotyledons 
and eophyll also exhibited increased growth below the toxic threshold. Examination of these structures by SEM confirmed these findings. The TEM examination provided additional support for these conclusions by providing photomicrographs that showed the lack of electron dense material at $0 \mathrm{ppm}$. and then an increase in electron dense material along the cell walls with increased concentrations ( 5 and $20 \mathrm{ppm}$ ).

As zinc levels increased to $10 \mathrm{ppm}$ and beyond, a definite change in seedling morphology occurred. The primary roots initially decreased in length by $28 \%$ and eventually become stunted at higher doses. The root hairs begin to shorten in length and eventually become vestigial. The cotyledons and eophyll also exhibited the toxic effects by diminished surface area and overall length.

It is evident that zinc is a required nutrient for growth and can have a beneficial effect at low doses above the minimum levels required for growth. As zinc levels increase, a definite tozic threshold is exhibited. Although this level varied with different plant species, it is usually marked by classic symptoms of diminished growth (roots and leaves) or yields (wet or dry weight).

The scanning and transmission electron microscopes are valuable research tools to help ezamine these effects. The SEM provided a detailed examination of changes in surface morphology. The TEM has the potential of providing detailed subcellular information. The TEM can provide the valuable link between changes in surface morphology to the changes and effects occurring in the plant cell and its components. 
This study has explored the potential use of these powerful tools in providing additional evidence and information in the area of metal toxicity. The lettuce seedling provides an ideal biological indicator species for the effects of toxic materials. The seedlings exhibited distinct morphological changes that can be easily measured by light and electron microscopy. 


\section{REFERENCES}

Beckett, P. H. \& Davis, R.D. (1977). Upper critical levels of toxic elements in plants. New Phytol., 79: 95-106.

Berry, W.L. (1977). Dose-response curves for lettuce subjected to acute toxic levels of copper and zinc. In, Biological implications of metals in the environment. Proceedings of the 15 th annual Hanford Life Sciences Symposium. pp 365-369.

Brown, M.T. \& Wilkins, D.A. (1985). Zinc tolerance in Betula. New Phytol., 99: 91-100.

Brown, M.T. \& Wilkins, D.A. (1986). The effects of zinc on germination, survival and growth of Betula seed. Environ. Pollut.(Series A)., 41: 53-61.

Collins, J.C. (1981). Effects of trace metals on plant function. In, Effects of Heavy Metal Pollution on Plants. Applied Science Publishers Inc. Englewood, New Jersey. pp. 145-169.

Davis, R.D. \& Beckett, P.H.T. (1978). Upper critical levels of toxic elements in plants. II. Critical levels of copper in young barley, wheat, rape, lettuce and ryegrass, and of nickel and zinc in young barley and ryegrass. New Phytol., 80: 23-32.

Dilling. W.J. (1926). Influence of lead and the metallic ions of copper, zinc, thorium, beryllium and thallium on the germination of seeds. Ann. Appl. Biol. 13:160-167.

Ernst, W. (1972). Zinc and cadmium pollution of soils and plants in the vacinity of a zinc smelting plant. Ber. dt. Bot. Gez. 85: 295-300.

Godbold, D.L., Horst, W.J., Collins, J.C., Thurman, D.A. and Marschner, H. (1984). Accumulation of zinc and organic acids in roots of zinc tolerant and non-tolerant ecotypes of Deschampsia caespitosa. J. Plant Physiol. 116: 59-69. 
Godbold, D.L. \& Huttermann, A. (1985). Effect of zinc, cadmium and mercury on root elongation of Picea abies (Karst.) seedlings, and the signifcance of these metals to forest die-back. Environ. Pollut.(Series A)., 38: 375-381.

Korcak, R.F. (1986). Growth of apple seedlings on sludge-amended soil in the greenhouse. Commun. Soil Sci. Plant Anal. 17(10): 1041-1054.

Nag, P., Nag, P., Paul, A.K., \& Mukherji, S. (1984). Toxic action of zinc on growth and enzyme activities of rice Oryza sativa $L$. seedlings. Environ. Pollut.(Series A)., 36: 45-59.

Ohki, K. (1975). Lower and upper critical zinc levels in relation to cotton growth and development. Physiol. plant. 35: 96-100.

Ohki, K. (1978). Zinc concentration in soybean as related to growth, photosynthesis, and carbonic anhydrase activity. Crop Sci. 18: 79-82.

Paivoke, A. (1983) The short-time effects of zinc on the growth, anatomy, and acid phosphatase activity of pea seedlings. Ann. Bot. Fenn. 20: 197-203.

Patel, P.M., Wallace, A. \& Mueller, R.T. (1976). Some effects of copper, cobalt, cadmium, zinc, nickel, and chromium on growth and mineral concentration in chrysanthemum. J. Amer. Soc. Hort. Sci.101(5): 553-556.

Pendias, A.K. \& Pendias, H. (1984). Trace Elements in Soil and Plants. CRC Press Inc. Boca Raton, Florida.

Rauser, W.E. (1973). Zinc tozicity in hydroponic culture. Can. J. Bot. 51: 301-304.

Rauser, W.E. \& Dumbroff, E.B. (1981). Effects of excess cobalt, nickel and zinc on the water relations of Phaseolus vulgaris. Environ. Exp. Bot. 21 (2): 249-255. 
Raven, P.H., Evert, R.F. and Curtis H. (1976) Biology of Plants. Worth Publishers, Inc. New York N.Y. 685 pp.

Robb, J., Busch, L. \& Rauser, W.E. (1980). Zinc toxicity and xylem vessel wall alterations in white beans. Ann. Bot., 46: 43-50.

Savage, W., Berry, W.L. \& Reed, C.A. (1981). Effects of trace element stress on the morphology of developing seedlings of lettuce (Lactuca sativa L. Grand Rapids) as shown by scanning electron microscopy. J Plant Nutr. 3(1-4): 129-138.

Tiffin, L.0. (1977). The form and distribution of metals in plants: an overview. In, Biological Implications of Metals in the Environment. Proceedings of the 15th Annual Hanford Life Sciences Symposium. pp. 314-334.

Turner, R.G. and Marshall C. (1971). The accumulation of $65 \mathrm{Zn}$ by root homogenates of zinc-tolerant and non-tolerant clones of Agrostis tenius. New Phytol. 70: 539-545.

Vallee, B.L. (1976). Zinc Biochemisty: A perspective. Trends Biochem Sciences. April: 88-91.

Veltrup, W. (1978). Characteristics of zinc uptake by barley roots. Physiol. Plant. 42: 190-194.

Wallace, A. \& Romney, E.M. (1977) Roots of higher plants as a barrier to translocation of some metals to shoots of plants. In, Biological Implications of Metals in the Environment. Proceedings of the 15 Annual Hanford Life Sciences Symposium. pp. 370-379.

Wallace, A., Romney, E.M. \& Alezander, G.V. (1980). Zinc-cadmium inter-actions on the availability of each to bush bean plants grown in solution culture. J. Plant Nutr. 2(1\&2): 51-54.

Wallace, A. (1982). Additive, protective, and synergistic effects on plant with excess trace elements. Soil Sci. $133(5): 319-323$. 
Wilkins, D.A. (1978). The measurement of tolerance to edaphic factors by means of root growth. New Phytol. 80: 623-633.

Wu, L. and Antonovics, J. (1975). Zinc and copper uptake by Agrostis stolonifera tolerant to both zinc and copper. New Phytol. 75: 231-237. 